Review

\title{
Current Therapies in Clinical Trials of Parkinson's Disease: A 2021 Update
}

\author{
E. Maruthi Prasad ${ }^{1}$ and Shih-Ya Hung ${ }^{1,2, *(\mathbb{D}}$ \\ 1 Graduate Institute of Acupuncture Science, China Medical University, Taichung 40402, Taiwan; \\ emaruthip@gmail.com \\ 2 Department of Medical Research, China Medical University Hospital, Taichung 40447, Taiwan \\ * Correspondence: shihyahung@mail.cmu.edu.tw
}

check for

updates

Citation: Prasad, E.M.; Hung, S.-Y.

Current Therapies in Clinical Trials of Parkinson's Disease: A 2021 Update. Pharmaceuticals 2021, 14, 717. https:// doi.org/10.3390/ph14080717

Academic Editors: Lusine Danielyan and Huu Phuc Nguyen

Received: 23 June 2021

Accepted: 22 July 2021

Published: 25 July 2021

Publisher's Note: MDPI stays neutral with regard to jurisdictional claims in published maps and institutional affiliations.

Copyright: (c) 2021 by the authors. Licensee MDPI, Basel, Switzerland. This article is an open access article distributed under the terms and conditions of the Creative Commons Attribution (CC BY) license (https:// creativecommons.org/licenses/by/ $4.0 /)$.

\begin{abstract}
Parkinson's disease (PD) is a progressive neurodegenerative disorder that currently has no cure, but treatments are available to improve PD symptoms and maintain quality of life. In 2020, about 10 million people worldwide were living with PD. In 1970, the United States Food and Drug Administration approved the drug levodopa as a dopamine replacement to manage PD motor symptoms; levodopa-carbidopa combination became commercialized in 1975. After over 50 years of use, levodopa is still the gold standard for PD treatment. Unfortunately, levodopa therapy-induced dyskinesia and OFF symptoms remain unresolved. Therefore, we urgently need to analyze each current clinical trial's status and therapeutic strategy to discover new therapeutic approaches for PD treatment. We surveyed 293 registered clinical trials on ClinicalTrials.gov from 2008 to 16 June 2021. After excluded levodopa/carbidopa derivative add-on therapies, we identified 47 trials as PD treatment drugs or therapies. Among them, 19 trials are in phase I (41\%), 25 trials are in phase II $(53 \%)$, and 3 trials are in phase III $(6 \%)$. The three phase-III trials use embryonic dopamine cell implant, $5-\mathrm{HT}_{1 \mathrm{~A}}$ receptor agonist (sarizotan), and adenosine $\mathrm{A}_{2 \mathrm{~A}}$ receptor antagonist (caffeine). The therapeutic strategy of each trial shows 29, 5, 1, 5, 5, and 2 trials use small molecules, monoclonal antibodies, plasma therapy, cell therapy, gene therapy, and herbal extract, respectively. Additionally, we discuss the most potent drug or therapy among these trials. By systematically updating the current trial status and analyzing the therapeutic strategies, we hope this review can provide new ideas and insights for PD therapy development.
\end{abstract}

Keywords: $\alpha$-synuclein; clinical trials; dopamine receptor agonists; gene therapy; levodopa; Parkinson's disease; plasma therapy

\section{Introduction}

Parkinson's disease (PD) is a chronic progressive movement disorder that is the second leading cause of neurodegenerative diseases after Alzheimer's disease. PD diagnosis is mainly based on brain imaging, neurological signs, and clinical symptoms [1]. Dopaminergic neuronal death in the substantia nigra of the midbrain causes striatal dopamine deficiency, which response to PD motor symptoms [2]. The motor symptoms in PD patients include slowness of movement, rigidity, tremor, freezing, muscle cramps, and dystonia [3]. The onset age of idiopathic (typical) PD patients is between 65 and 70 years old [4]. About $5 \%$ to $10 \%$ of patients acquire early-onset PD, which onsets before 50 years old [5]. Earlyonset PD is often inherited and related to specific genetic mutations [6]. In PD-related genes, $\alpha$-synuclein is a presynaptic neuronal protein $(14-19 \mathrm{kDa})$ that regulates synaptic integrity and cellular functions [7]. $\alpha$-Synuclein is one of the pathogenic hallmarks in PD; $\alpha$-synuclein accumulates in Lewy bodies and associates with neuroinflammation during PD progression [8].

Using levodopa to improve PD motor symptoms is a gold standard. Levodopa was synthesized by a polish biochemist Casimir Funk in 1911 [9]. In 1961, levodopa was clinically examined in 20 PD patients by Walter Birkmayer, and he observed miraculous motor 
improvement for a few hours. In 1968, George Cotzias et al. used the oral form of levodopa tested in 28 PD subjects and revealed successful data for motor improvements [9]. In 1970, the United States Food and Drug Administration approved levodopa as a dopamine replacement to manage PD motor symptoms [9]. Subsequently, the first combined form of levodopa and carbidopa was used for controlling the motor symptoms in 1975 [10]. In combined form, levodopa converts dopamine by dopamine decarboxylase, activating dopamine receptors responsible for improving motor functions in the central nervous system and peripheral circulation [11]. Carbidopa acts as a decarboxylase inhibitor to facilitate levodopa availability in the brain [11]. The most common side effects of levodopa plus carbidopa combination include nausea, motor problems, hallucinations, depression, low blood pressure, irregular sleep, and gambling compulsions [12-14]. For more than 50 years, levodopa is still a standard in PD drug treatment. Unfortunately, levodopa treatment-induced dyskinesia and OFF symptoms remain unresolved; one report shows that dyskinesia and OFF symptoms occur in $13.5 \%$ and $55.9 \%$ of the study population, respectively [15]. The mechanism of long-term levodopa therapy-induced dyskinesia is not fully clear [16]. It indicates the urgent need for exploring new therapeutic strategies for PD treatment.

Disease-modification and neuroprotection are important therapeutic strategies to improve PD motor symptoms via inhibition or slow-down dopaminergic neuronal death in the brain [17]. Currently, available PD medications are only short-lived, such as levodopa [18]. Many drugs or therapy have shown definite neuroprotection in dopaminergic neurons in vivo and in vitro; several failed when tested in clinical trials. Figure 1A depicts that dopaminergic neuronal death, $\alpha$-synuclein aggregates, mitochondrial dysfunction, reactive oxygen species, apoptosis, and neuroinflammation are the pathological hallmarks of PD [19]. PD is a multifactorial disorder involving aging, genetics, and environmental factors. Figure 1B elucidates the impact of aging, environmental hazards, and genetic factors in PD progression.

Evaluation of new drugs is monitored carefully in clinical trials. According to the United States Food and Drug Administration, the purposes of phase I are safety and dosage; approximately $70 \%$ of drug/therapy moves to phase II [20]. The purpose of phase II is to test efficacy and side effects; more or less $33 \%$ of drugs move to phase III [20]. Phase III is to study the potency and monitoring of adverse reactions [20]. In 2000, the United States National Library of Medicine created the web-based registry "ClinicalTrials.gov" for users to search the clinical trial information, including study design, methods, results, expected end dates, etc. The data is maintained or updated by sponsors worldwide. To date, the clinical trials' registry consists of over $2700 \mathrm{PD}$ clinical studies. Clinical trial outcomes/endpoints are considered comparative effectiveness research [21], and outcomes can be achieved using various strategies such as cognitive or behavioral scores, magnetic resonance imaging, positron emission tomography, electrophysiological monitoring, or biological biomarkers. Each clinical trial is developed and assessed for treatment benefits to prevent adverse events [21]. In clinical trials, post-approval is required for comparative research to compare clinical trials with available standard medicines/therapy, which provides quality of life, safety, and tolerance to obtain efficient data in the larger patients' population [21]. Primary endpoints are essential and sufficient to establish the efficacy of a drug/therapy in clinical trials. Based on the primary endpoints, secondary endpoints are sufficient to claim/labeling the efficacy of the clinical trial study, and the exploratory/tertiary endpoints support descriptive information [22]. Levodopa is used to treat PD for over 50 years, and levodopa therapy-induced dyskinesia and OFF symptoms remain unresolved. Therefore, we urgently need to analyze each current clinical trial's status and therapeutic strategy and discover new therapeutic approaches for PD treatment. In this review, we have screened the clinical trial pipeline data from Clinicaltrials.gov to analyze PD therapies. First, we excluded levodopa/carbidopa derivatives add-on therapy to select 293 clinical trials. Among those, we identified forty-seven clinical trials that belong to new PD therapeutic strategies by the following conditions and filters in Figure 2. 
A

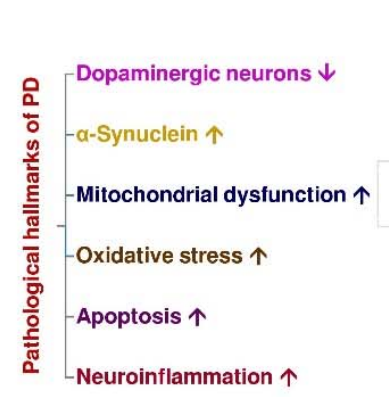

B

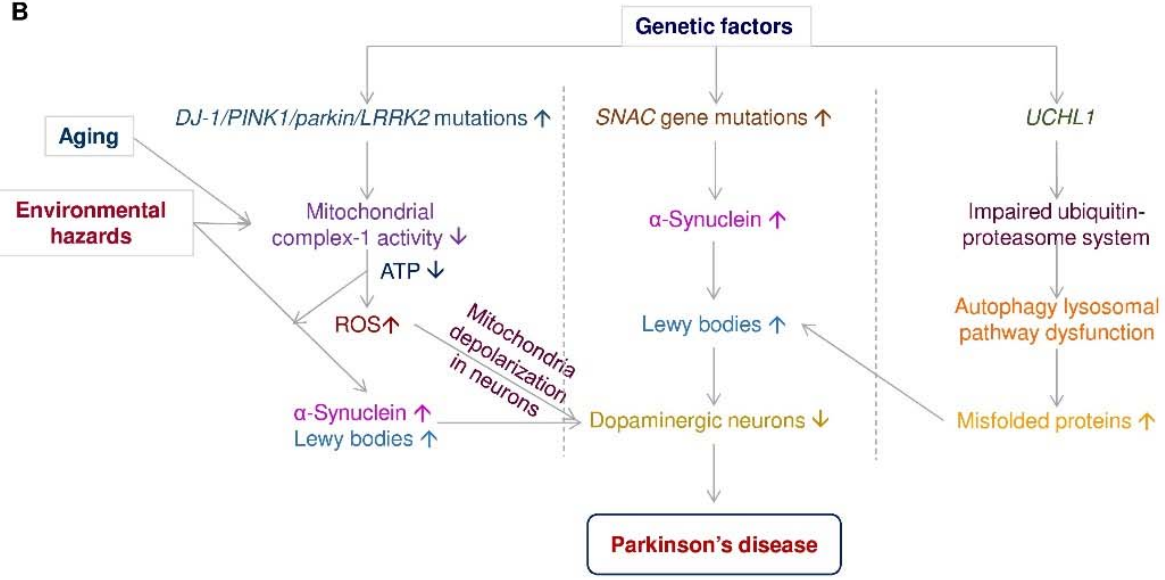

Figure 1. The pathological hallmarks of PD and the interplay of aging, environmental hazards, and genetics in the pathogenesis of PD. (A) The pathological hallmarks of Parkinson's disease include dopaminergic neuronal death, $\alpha$ synuclein aggregates, mitochondrial dysfunction, reactive oxygen species, apoptosis, and neuroinflammation. (B) PD is a multifactorial disorder involving aging, genetics, and environmental factors, associated with dopaminergic neuronal death. Gene mutations associate with PD includes DJ-1, PTEN-induced putative kinase-1 (PINK1), parkin, leucine-rich repeat serine/threonine kinase-2 (LRRK2), Synuclein alpha (SNAC), and ubiquitin carboxyl-terminal hydrolase-L1 (UCHL1). Neurotoxins (e.g., rotenone, paraquat) and gene mutations of DJ-1, PINK1, parkin, LRRK2, and SNAC induce mitochondria complex I inhibition, ATP depletion, reactive oxygen species (ROS) accumulation, mitochondria depolarization, and mitochondrial dysfunction in dopaminergic neurons to promote neuronal death in the substantia nigra of PD patients. Overexpression of SNAC gene mutations enhance $\alpha$-synuclein aggregation in Lewy bodies of PD brain. UCHL1 gene mutations impair ubiquitin-proteasome systems and further induce autophagy lysosomal pathway dysfunction, contributing to Lewy body formation in dopaminergic neurons.

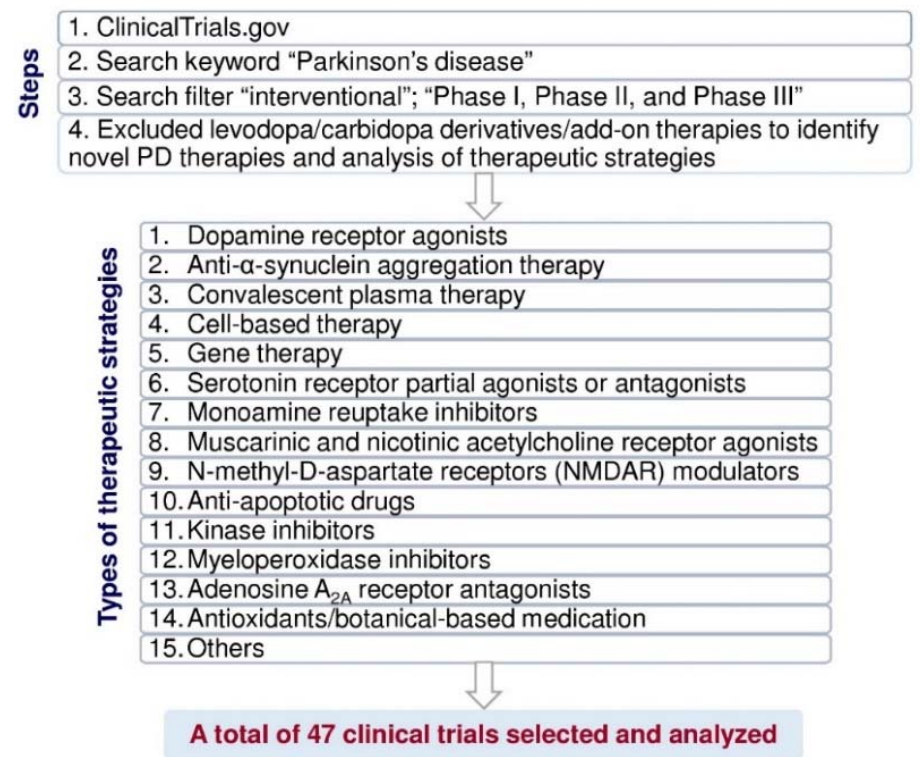

Figure 2. Flow diagram of the method used to select and analyze the clinical trial data for PD treatment from ClinicalTrials.gov (https: / / clinicaltrials.gov, accessed on 16 June 2021).

\section{PD Therapeutic Strategies in Clinical Trials}

In Figure 2, we have classified these therapeutic strategies into 15 types: dopamine receptor agonists, anti- $\alpha$-synuclein aggregation therapy, convalescent plasma therapy, cellbased therapy, gene therapy, serotonin receptor partial agonists or antagonists, monoamine reuptake inhibitors, muscarinic and nicotinic acetylcholine receptor agonists, N-methyl-Daspartate receptor (NMDAR) modulators, anti-apoptotic drugs, kinase inhibitors, myeloper- 
oxidase inhibitors, adenosine $\mathrm{A}_{2 \mathrm{~A}}$ receptor antagonists, antioxidants/botanical-based medication, and others. Figure 3 depicts the type of drug or therapy, mechanisms, and the current drugs/treatments in PD.

Therapeutic strategy

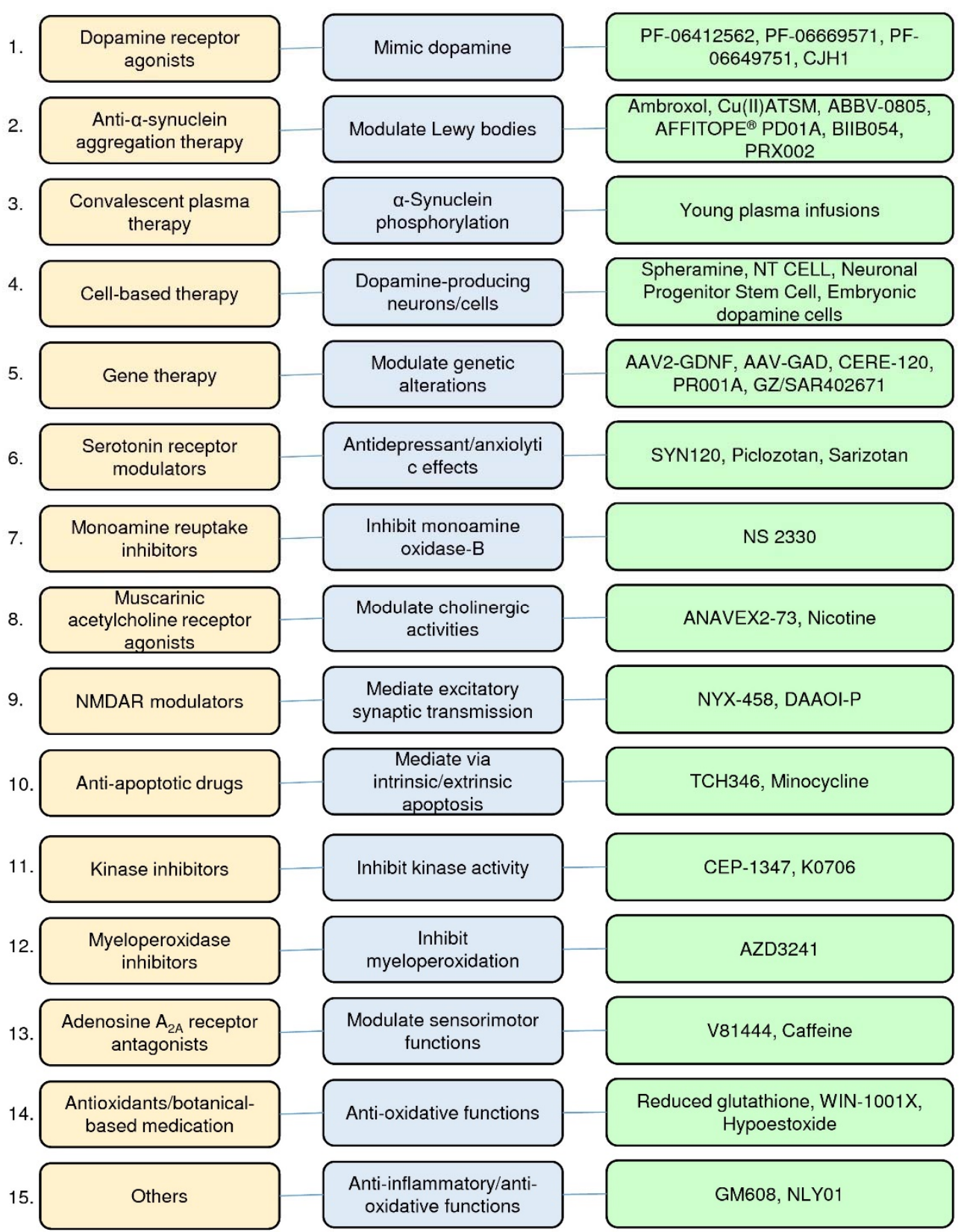

Figure 3. The type of therapeutic strategies, mechanism, and the current drugs/therapies in the clinical trials of PD treatment.

After analyzing the data collected from ClinicalTrials.gov, we identified forty-seven registered interventional clinical trials in phases I, II, and III as new PD therapies based on the current trial status that shows ongoing/updated or discontinued as of 16 June 2021. Among the forty-seven trials, 19 trials (41\%) in phase I, $25(53 \%)$ in phase II, and $3(6 \%)$ in phase III (Figure 4A; the phase I/II or II/III trials on ClinicalTrials.gov are considered phase I or II, respectively.) 
A The trial phases

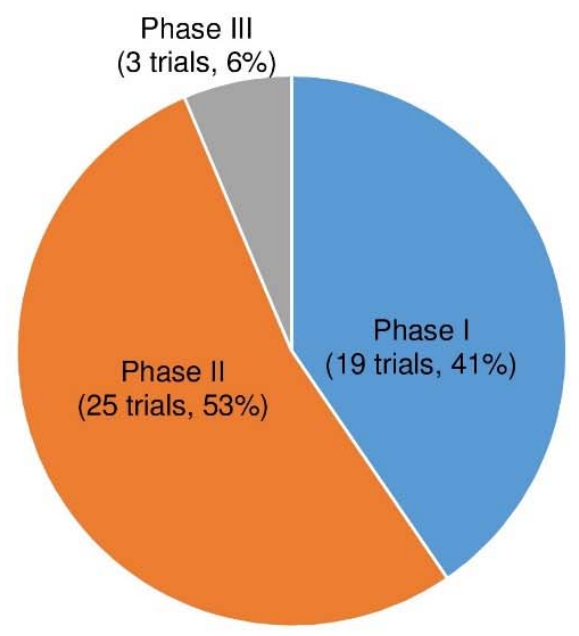

B

\section{Therapeutic strategies in trials}

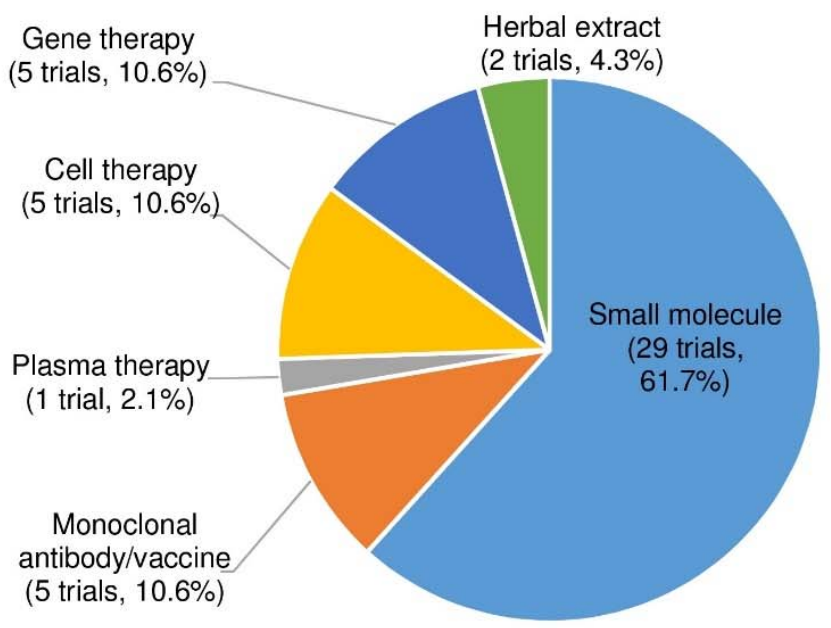

Figure 4. The trial phases and therapeutic strategies in the clinical trials for PD treatment. (A) A pie chart shows the individual percentage of phase I, phase II, and phase III trials to the total. The phase I/II or II/III trials on ClinicalTrials.gov are showed as phase I or II, respectively. (B) A pie chart shows the proportions of each therapeutic strategy to the total PD clinical trials.

Next, we divided the therapeutic strategy of each trial into the small molecule, monoclonal antibody, plasma therapy, cell therapy, gene therapy, and herbal extract. As a result, we found 29 clinical trials using small molecules $(61.7 \%), 5$ using monoclonal antibodies $(10.6 \%), 1$ using plasma therapy (2.1\%), 5 using cell-based therapies $(10.6 \%), 5$ using gene therapies (10.6\%), and 2 using herbal extracts (4.3\%) (Figure 4B).

The clinical trials data showed that the majority of the trials were small molecular therapeutic strategies in the PD trials. We found several PD therapies focused on neuroprotection and disease modification. Based on the trial status (ongoing, unknown, or discontinued), we found that the clinical trial status for the CJH1 (NCT01684475) and nicotine transdermal patch (NCT01560754) is unknown. Moreover, the clinical trials of PF06649751 (NCT02847650 and NCT02687542), GZ/SAR402671 (NCT02906020), CEP-1347 (NCT00040404), ABBV-0805 (NCT04127695), and BIIB054 (NCT03318523), spheramine (NCT00206687), and neuronal progenitor stem cell (NCT00927108) therapy were discontinued due to various reasons (Figure 5).

\subsection{Dopamine Receptor Agonists}

Dopamine receptor agonists are the main therapy class that mimics dopamine function in PD patients $[23,24]$. All the dopamine receptors are $G$ protein-coupled receptors containing $D_{1}$ and $D_{2}$ types; they pair with $G$ s of $G$ proteins, which trigger the adenylyl cyclase system and consequently rouse the cAMP synthesis [25]. $\mathrm{D}_{1}$ receptor contains $\mathrm{D}_{1}$ and $\mathrm{D}_{5}$ subtypes; $\mathrm{D}_{2}$ receptor contains $\mathrm{D}_{2}, \mathrm{D}_{3}$, and $\mathrm{D}_{4}$ subtypes [26,27]. Although upon the prolonged oral dopamine receptor agonists, treatment becomes unresponsive $[16,28]$. 


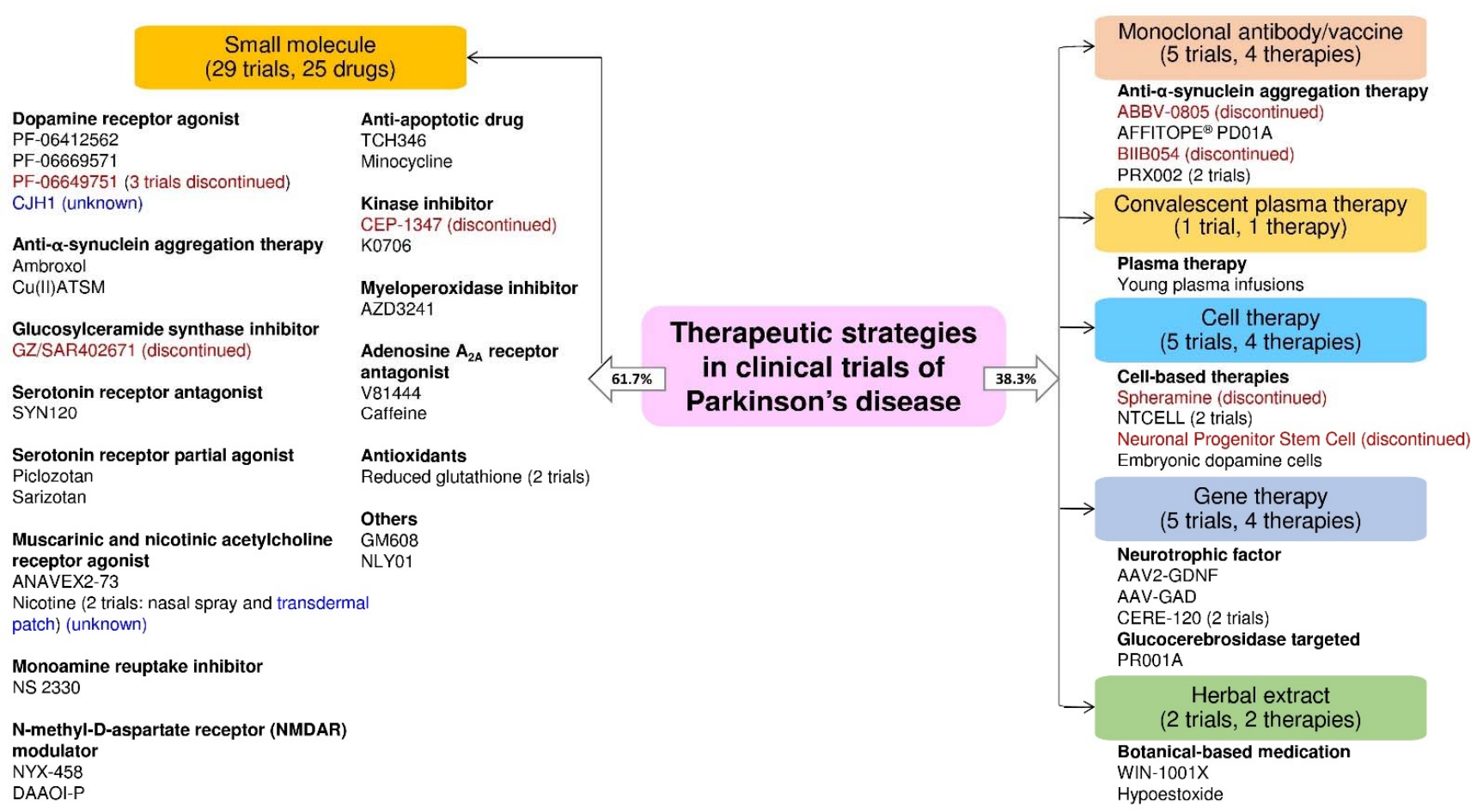

Figure 5. The drug or therapy with its therapeutic strategy and trial status in the clinical trials for PD treatment. The blue and red text color indicates the trial status is unknown and discontinued, respectively (active as of 16 June 2021).

We found six clinical trials that used four small molecular drugs that act as a dopamine receptor agonist in PD treatment. PF-06412562 is a moderately potent, highly selective oral $\mathrm{D}_{1} / \mathrm{D}_{5}$ dopamine receptor partial agonist; $\mathrm{PF}-06412562$ has good selectivity than other dopamine receptor subtypes [29]. In a phase I trial, oral administration PF-06412562 had potential antiparkinsonian efficacy in $13 \mathrm{PD}$ patients without significant acute changes in cardiovascular parameters reported with previous $\mathrm{D}_{1}$ agonists (Table 1) (NCT03665454) [29]. The trial results revealed that the PF-06412562 was well tolerated in advanced PD patients and met the primary and secondary endpoints [30]. PF-06669571 is a novel and oral $\mathrm{D}_{1} / \mathrm{D}_{5}$ dopamine receptor partial agonist with a non-catechol-based structure that has demonstrated efficacy in preclinical models of PD symptoms [31]. Gurrell et al. (2018) showed that PF-06669571 (1 or $3 \mathrm{mg}$, four times a day) in the phase I trial was safe and welltolerated with minor adverse events such as nausea in 10 idiopathic PD patients (Table 1 ) (NCT02565628) [31]. PF-06649751 is also a novel, oral, non-catechol, $\mathrm{D}_{1} / \mathrm{D}_{5}$ dopamine receptor partial agonist [32]. In phase I study, PF-06649751 showed safety, efficacy, and tolerability with pharmacological profile; further phases of trials on a larger scale were carryout by Pfizer (Table 1) (NCT02224664) [32]. In addition, the phase II study PF-06649751 (1 daily oral dose) demonstrated significant motor balance improvement and was well-tolerated in 25 early-stage PD patients (NCT02847650) [33]. The study showed PF-06649751 treatment had the most common adverse events, including nausea, headache, dry mouth, somnolence, and tremor [33]. The phase II trials of PF-06649751 failed to demonstrate efficacy in moderate/advanced PD and were terminated (Table 1) (NCT02847650 and NCT02687542). The $\mathrm{D}_{2}$-specific dopamine receptor agonist CJH1 (CLR4001) is undergoing a phase I/II clinical trial developed by Alexandra Marine and General Hospital, and the current trial status has not been updated since 2012 (Table 1) (NCT01684475). Moreover, the clinical data of PF-06412562 ((4-[4-(4,6-dimethyl-5-pyrimidinyl)-3-methylphenoxyl]-1H-pyrazolo [4,3-c]pyridine) showed safety and tolerability against advanced PD (NCT03665454) [30]. The PF-06669571 treatment was also reported as safe and tolerable against idiopathic PD [31]. Among the three trials of PF-06649751, two (NCT02847650 and NCT02687542) were discontinued due to insufficient efficacy, and one trial shows phase I, but no post updated since March 2017 (NCT02224664). 
Long-term (1-5 years) usage of dopamine receptor agonists offers adverse effects based on the dosage. The side effects include nausea, vomiting, irregular heartbeats, low blood pressure, renal/pulmonary diseases, and dizziness [34]. Besides, extended dopamine receptor agonist usage causes chorea/dystonic movements, illusions, delusions, mania, mental disturbances, yawning, and irresistible sleep periods [34]. Several studies revealed that dopamine receptor agonists aid in drug-induced mental illness, anxiety, anorexia nervosa, schizophrenia, hypersexuality, gambling mentality, and compulsive shopping disorders [35]. Among currently used dopamine receptor agonists for PD treatment, pramipexole treatment might have maximum side effects [36].

\subsection{Anti- $\alpha$-Synuclein Aggregation Therapy}

$\alpha$-Synuclein, an unfolded highly soluble protein in presynaptic neurons of the brain [37]. $\alpha$-Synuclein aggregation is a pathologic hallmark of synucleinopathies in sporadic and hereditary PD [38]. Aggregation of $\alpha$-synuclein induces many pathological conditions such as autophagy or lysosomal disorder, synaptic dysfunction, mitochondrial dysfunction, endoplasmic reticulum stress, and oxidative stress [39,40]. All the pathological conditions further lead to proteinaceous cytoplasmic inclusions, known as Lewy bodies and Lewy neurites [40]. Anti- $\alpha$-synuclein aggregation treatment mainly increases the cellular clearance mechanisms and regulates Lewy bodies [41].

In anti- $\alpha$-synuclein aggregation therapies, we found five clinical trials that use monoclonal antibodies (ABVV-0805, BIIB054, and PRX002) or vaccines (AFFITOPE ${ }^{\circledR}$ PD01A), and two trials use small molecules (ambroxol and $\mathrm{Cu}(\mathrm{II}) \mathrm{ATSM}$ ) in the clinical trials for PD. In a phase I trial, monoclonal antibody ABVV-0805 has been withdrawn due to strategic considerations by AbbVie (Table 2) (NCT04127695). BIIB054 (cinpanemab) is an IgG 1 protein produced from memory $B$ cells from aged people without nervous system diseases [42]. BIIB054 treatment showed an 800-fold higher affinity towards binding to $\alpha$-synuclein that inhibited spread or aggregation and improved motor balances [42]. The current status of the BIIB054 (phase II) study shows termination due to not meeting the primary and secondary endpoints for the treatment of PD (Table 2) (NCT03318523).

Anti- $\alpha$-synuclein monoclonal antibody PRX002 (RO7046015/prasinezumab) is developing (phase II) by Hoffmann-La Roche (NCT03100149). In addition, a phase-I study used PRX002 that targets anti- $\alpha$-synuclein is developing by Prothena Bio-sciences Limited (Table 2) (NCT02157714). Jankovic et al. (2018) showed that single and multiple doses of the anti- $\alpha$-synuclein monoclonal antibody PRX002 were generally safe and well-tolerated, and it resulted in robust binding of peripheral $\alpha$-synuclein and dose-dependent increases of PRX002 in cerebrospinal fluid (Table 2) (NCT03100149) [43]. AFFITOPE ${ }^{\circledR}$ PD01A is a phase I experimental vaccine made by short synthetic peptides to produce antibodies against $\alpha$-synuclein aggregation and improve immunity, developed by Affiris AG (Table 2) (NCT01568099) [44]. The same vaccine AFFITOPE ${ }^{\circledR}$ PD01A trials were also registered with NCT01885494, NCT02216188, and NCT02618941 by Affiris AG (Table 2) [44]. AFFITOPE ${ }^{\circledR}$ PD01A demonstrated safe and well-tolerated in patients; the trials also showed increased antibodies in the blood and cerebrospinal fluid extended by Affiris AG for further studies [44,45]. Ambroxol is a potential disease-modifying small molecule that targets $\alpha$-synuclein aggregation (Table 1). Since 1979, ambroxol has been using as a drug for cough [46]. A report indicates ambroxol blocks autophagy and driving cargo towards the secretory pathway [47]. To date, the ambroxol administration has not been reported for severe side effects; more or less, it may cause gastric ulceration [46]. Mullin et al. (2020) showed that ambroxol therapy could cross the blood-brain barrier, dock with the enzyme $\beta$-glucocerebrosidase, and decrease cerebrospinal fluid $\alpha$-synuclein level in PD patients without glucocerebrosidase genetic mutations [48]. The preclinical data of ambroxol reduced $\alpha$-synuclein aggregation and lowered the disease progression [48,49]. The Lawson Health Research Institute is developing ambroxol as an anti-PD drug. The current status is under subject recruitment at phase II without result, and the study is estimated to be completed by December 2021 (NCT02914366). Next, Copper (II) diacetylbis (N(4)-methyl 
thio semi carbazonato) ( $\mathrm{Cu}$ (II)ATSM) is a small molecule permeable to the blood-brain barrier, which is currently in a phase I trial for PD treatment developing by Collaborative Medicinal Development Pty Limited. Cu(II)ATSM treatment improves neuroprotection by cognitive and motor performances via modulating brain metal levels and dopamine metabolism in animal models [50]. The trial status of $\mathrm{Cu}$ (II)ATSM shows that subject recruiting is complete, and no published data are available (Table 1) (NCT03204929).

Recent literature shows that the use of small molecules against $\alpha$-synuclein aggregation is safe and efficient by increasing autophagy/lysosomal flux than other PD therapies [40], for instance, ambroxol or Cu(II)ATSM small molecule $\alpha$-synuclein target drugs being tested in the pipeline of clinical trials, and could be successful drugs in future. In $\mathrm{PD}, \alpha$-synuclein aggregates induce neuronal loss, one of the key factors associated with neuroinflammation [51]. Nevertheless, the long-term usage of $\alpha$-synuclein targeted therapies may also cause several side effects such as loss of synaptic functions and disruption of endoplasmic reticulum-Golgi stress [52]. 


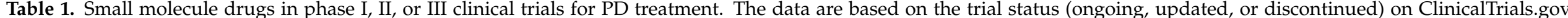
(https: / / clinicaltrials.gov) that is active as of 16 June 2021.

\begin{tabular}{|c|c|c|c|c|c|c|c|}
\hline Therapeutic Strategy & Classification & Name & PD Subjects & Trial Status & $\begin{array}{c}\text { Reasons for } \\
\text { Discontinuation }\end{array}$ & Sponsor & $\begin{array}{l}\text { ClinicalTrials.gov } \\
\text { Identifier and } \\
\text { Reference }\end{array}$ \\
\hline $\begin{array}{l}\text { Dopamine } \\
\text { receptor agonists }\end{array}$ & $\begin{array}{c}\text { Small molecular } \\
\text { Dopamine } \mathrm{D}_{1} / \mathrm{D}_{5} \text { partial } \\
\text { agonist }\end{array}$ & PF-06412562 & Advanced-stage PD & Phase I & Not applicable & $\begin{array}{l}\text { Milton S. Hershey } \\
\text { Medical Center }\end{array}$ & NCT03665454 [30] \\
\hline $\begin{array}{l}\text { Dopamine } \\
\text { receptor agonists }\end{array}$ & $\begin{array}{c}\text { Small molecular } \\
\text { Dopamine } \mathrm{D}_{1} \text { partial agonist }\end{array}$ & PF-06669571 & Idiopathic PD & Phase I & Not applicable & Pfizer & NCT02565628 [31] \\
\hline $\begin{array}{l}\text { Dopamine } \\
\text { receptor agonists }\end{array}$ & $\begin{array}{c}\text { Small molecular } \\
\text { Dopamine } \mathrm{D}_{1} / \mathrm{D}_{5} \text { partial } \\
\text { agonist }\end{array}$ & PF-06649751 & Idiopathic PD & Phase I & Not applicable & Pfizer & NCT02224664 [32] \\
\hline $\begin{array}{l}\text { Dopamine } \\
\text { receptor agonists }\end{array}$ & $\begin{array}{c}\text { Small molecular } \\
\text { Dopamine } \mathrm{D}_{1} / \mathrm{D}_{5} \text { partial } \\
\text { agonist }\end{array}$ & PF-06649751 & Early stage PD & $\begin{array}{c}\text { Phase II } \\
\text { discontinued }\end{array}$ & $\begin{array}{c}\text { Terminated due to lack } \\
\text { of efficacy in } \\
\text { moderate/advanced } \\
\text { PD. }\end{array}$ & Pfizer & NCT02847650 [33] \\
\hline $\begin{array}{l}\text { Dopamine } \\
\text { receptor agonists }\end{array}$ & $\begin{array}{c}\text { Small molecular } \\
\text { Dopamine } \mathrm{D}_{1} / \mathrm{D}_{5} \text { partial } \\
\text { agonist }\end{array}$ & PF-06649751 & $\begin{array}{l}\text { PD with motor } \\
\text { fluctuations }\end{array}$ & $\begin{array}{c}\text { Phase II } \\
\text { discontinued }\end{array}$ & $\begin{array}{l}\text { Terminated due to } \\
\text { insufficient efficacy. }\end{array}$ & Pfizer & NCT02687542 \\
\hline $\begin{array}{l}\text { Dopamine } \\
\text { receptor agonists }\end{array}$ & $\begin{array}{c}\text { Small molecular } \\
\text { Dopamine } \mathrm{D}_{2} \text { agonist }\end{array}$ & CJH1 (CLR4001) & PD patients & Phase I/II & Unknown & $\begin{array}{l}\text { Alexandra Marine and } \\
\text { General Hospital }\end{array}$ & NCT01684475 \\
\hline $\begin{array}{l}\text { Anti- } \alpha \text {-synuclein } \\
\text { aggregation } \\
\text { therapy }\end{array}$ & $\begin{array}{c}\text { Small molecular } \\
\text { Peroxynitrite scavenger }\end{array}$ & $\mathrm{Cu}(\mathrm{II}) \mathrm{ATSM}$ & Early idiopathic PD & Phase I & Not applicable & $\begin{array}{c}\text { Collaborative Medicinal } \\
\text { Development Pty } \\
\text { Limited }\end{array}$ & NCT03204929 \\
\hline Gene therapy & $\begin{array}{c}\text { Small molecular } \\
\text { glucocerebrosidase }(G B A) \text { gene } \\
\text { mutating therapy }\end{array}$ & GZ/SAR402671 & Early stage PD & $\begin{array}{c}\text { Phase II } \\
\text { discontinued }\end{array}$ & $\begin{array}{l}\text { Terminated due to not } \\
\text { meeting the primary } \\
\text { and secondary } \\
\text { endpoints. }\end{array}$ & Genzyme & NCT02906020 [53] \\
\hline
\end{tabular}


Table 1. Cont.

\begin{tabular}{|c|c|c|c|c|c|c|c|}
\hline Therapeutic Strategy & Classification & Name & PD Subjects & Trial Status & $\begin{array}{c}\text { Reasons for } \\
\text { Discontinuation }\end{array}$ & Sponsor & $\begin{array}{l}\text { ClinicalTrials.gov } \\
\text { Identifier and } \\
\text { Reference }\end{array}$ \\
\hline $\begin{array}{l}\text { Serotonin } \\
\text { receptor agonists or } \\
\text { antagonists }\end{array}$ & $\begin{array}{c}\text { Small molecular } \\
\text { Dual 5- } \mathrm{HT}_{6 / 5}-\mathrm{HT}_{2} \text { antagonist }\end{array}$ & SYN120 & PD with dementia & Phase II & Not applicable & Biotie Therapies Inc. & NCT02258152 \\
\hline $\begin{array}{l}\text { Serotonin } \\
\text { receptor agonists or } \\
\text { antagonists }\end{array}$ & $\begin{array}{l}\text { Small molecular } \\
\text { Selective } 5-\mathrm{HT}_{1 \mathrm{~A}} \text { partial agonist }\end{array}$ & $\begin{array}{l}\text { Piclozotan } \\
\text { (SUN N4057) }\end{array}$ & Idiopathic PD & Phase II & Not applicable & Daiichi Sankyo, Inc. & NCT00623363 \\
\hline $\begin{array}{l}\text { Serotonin } \\
\text { receptor agonists or } \\
\text { antagonists }\end{array}$ & $\begin{array}{l}\text { Small molecular } \\
\text { Selective } 5 \text { - } \text { HT }_{1 \mathrm{~A}} \text { agonist and } \mathrm{D}_{2} \\
\text { antagonist }\end{array}$ & Sarizotan & Idiopathic PD & Phase III & Not applicable & EMD Serono & NCT00105508 [54] \\
\hline $\begin{array}{l}\text { Monoamine reuptake } \\
\text { inhibitors }\end{array}$ & $\begin{array}{c}\text { Small molecular } \\
\text { Triple monoamine reuptake } \\
\text { inhibitor (serotonin, } \\
\text { noradrenaline, and dopamine } \\
\text { reuptake inhibitor) }\end{array}$ & NS 2330 (tesofensine) & Early stage PD & Phase II & Not applicable & Boehringer Ingelheim & NCT00148486 \\
\hline $\begin{array}{l}\text { Muscarinic and } \\
\text { nicotinic } \\
\text { acetylcholine } \\
\text { receptor agonists }\end{array}$ & $\begin{array}{c}\text { Small molecular } \\
\text { Muscarinic agonist and sigma1 } \\
\text { agonist }\end{array}$ & ANAVEX2-73 & $\begin{array}{l}\text { PD with } \\
\text { dementia }\end{array}$ & Phase II & Not applicable & $\begin{array}{l}\text { Anavex Life Sciences } \\
\text { Corp. }\end{array}$ & NCT04575259 \\
\hline $\begin{array}{l}\text { Muscarinic and } \\
\text { nicotinic } \\
\text { acetylcholine } \\
\text { receptor agonists }\end{array}$ & $\begin{array}{l}\text { Small molecular } \\
\text { Nicotinic agonist }\end{array}$ & $\begin{array}{l}\text { Nicotine transdermal } \\
\text { patch }\end{array}$ & Early stage PD & Phase II & Unknown & James BOYD MD & NCT01560754 \\
\hline $\begin{array}{l}\text { Muscarinic and } \\
\text { nicotinic } \\
\text { acetylcholine } \\
\text { receptor agonists }\end{array}$ & $\begin{array}{l}\text { Small molecular } \\
\text { Nicotinic agonist }\end{array}$ & Nicotine nasal spray & $\begin{array}{l}\text { PD (Hoehn and } \\
\text { Yahr stage 2-3) }\end{array}$ & Phase II & Not applicable & $\begin{array}{l}\text { El Instituto Nacional de } \\
\text { Neurologia y } \\
\text { Neurocirugia Manuel } \\
\text { Velasco Suarez }\end{array}$ & NCT03865121 \\
\hline $\begin{array}{l}\text { N-methyl-D-aspartate } \\
\text { receptor (NMDAR) } \\
\text { modulators }\end{array}$ & $\begin{array}{l}\text { Small molecular } \\
\text { NMDAR modulator }\end{array}$ & NYX-458 & $\begin{array}{c}\text { Mild cognitive } \\
\text { impairment } \\
\text { associated with PD }\end{array}$ & Phase II & Not applicable & Aptinyx & NCT04148391 \\
\hline $\begin{array}{l}\text { NMDAR } \\
\text { modulator }\end{array}$ & $\begin{array}{c}\text { Small molecular } \\
\text { D-amino acid oxidase inhibitor }\end{array}$ & DAAOI-P & $\begin{array}{l}\text { PD with } \\
\text { dementia }\end{array}$ & Phase II & Not applicable & $\begin{array}{c}\text { China Medical } \\
\text { University Hospital }\end{array}$ & NCT04470037 \\
\hline
\end{tabular}


Table 1. Cont.

\begin{tabular}{|c|c|c|c|c|c|c|c|}
\hline Therapeutic Strategy & Classification & Name & PD Subjects & Trial Status & $\begin{array}{c}\text { Reasons for } \\
\text { Discontinuation }\end{array}$ & Sponsor & $\begin{array}{l}\text { ClinicalTrials.gov } \\
\text { Identifier and } \\
\text { Reference }\end{array}$ \\
\hline Anti-apoptotic drugs & $\begin{array}{c}\text { Small molecular } \\
\text { Dibenz[b,f]oxepin-10-ylmethyl- } \\
\text { prop-2-ynyl-amine, hydrogen } \\
\text { maleate salt }\end{array}$ & ТCH346 & Early stage PD & Phase I/II & Not applicable & Novartis & NCT00407212 \\
\hline Anti-apoptotic drugs & $\begin{array}{c}\text { Small molecular } \\
\text { Synthetic tetracycline derivative }\end{array}$ & Minocycline & $\begin{array}{c}\text { Early stage } \\
\text { untreated PD }\end{array}$ & Phase II & Not applicable & University of Rochester & NCT00063193 [55] \\
\hline Kinase inhibitors & $\begin{array}{l}\text { Small molecular } \\
\text { Semisynthetic inhibitor of the } \\
\text { mixed lineage kinase family }\end{array}$ & $\begin{array}{l}\text { CEP-1347 } \\
\text { (KT7515) }\end{array}$ & Early stage PD & $\begin{array}{l}\text { Phase II/III } \\
\text { discontinued }\end{array}$ & $\begin{array}{l}\text { Terminated due to } \\
\text { insufficient efficacy. }\end{array}$ & Cephalon & NCT00040404 [56] \\
\hline Kinase inhibitors & $\begin{array}{l}\text { Small molecular } \\
\text { Orally selective inhibitor of } \\
\text { cABL protein tyrosine kinase }\end{array}$ & K0706 & Early stage PD & Phase II & Not applicable & $\begin{array}{l}\text { Sun Pharma Advanced } \\
\text { Research Company } \\
\text { Limited }\end{array}$ & NCT03655236 \\
\hline $\begin{array}{l}\text { Myeloperoxidase } \\
\text { inhibitors }\end{array}$ & $\begin{array}{c}\text { Small molecular } \\
\text { Irreversible myeloperoxidase } \\
\text { inhibitor }\end{array}$ & AZD3241 & Idiopathic PD & Phase II & Not applicable & AstraZeneca & NCT01603069 \\
\hline $\begin{array}{c}\text { Adenosine } \mathrm{A}_{2 \mathrm{~A}} \text { receptor } \\
\text { antagonists }\end{array}$ & $\begin{array}{c}\text { Small molecular } \\
\text { Adenosine } \mathrm{A}_{2 \mathrm{~A}} \text { antagonist }\end{array}$ & V81444 & PD patients & Phase I & Not applicable & Vernalis (R\&D) Ltd. & NCT02764892 \\
\hline $\begin{array}{c}\text { Adenosine } \mathrm{A}_{2 \mathrm{~A}} \text { receptor } \\
\text { antagonists }\end{array}$ & $\begin{array}{c}\text { Small molecular } \\
\text { Selective Adenosine } \mathrm{A}_{2 \mathrm{~A}} \\
\text { antagonist }\end{array}$ & Caffeine & $\begin{array}{l}\text { PD (Hoehn and } \\
\text { Yahr stage 1-3) }\end{array}$ & Phase III & Not applicable & $\begin{array}{l}\text { McGill University } \\
\text { Health Centre/Research } \\
\text { Institute of the McGill } \\
\text { University Health } \\
\text { Centre }\end{array}$ & NCT01738178 [57] \\
\hline Antioxidants & $\begin{array}{l}\text { Small molecular } \\
\text { Intranasal glutathione therapy }\end{array}$ & Reduced glutathione & $\begin{array}{l}\text { PD (modified } \\
\text { Hoehn and Yahr } \\
\text { stage }<3 \text { ) }\end{array}$ & Phase I & Not applicable & Bastyr University & NCT01398748 \\
\hline Antioxidants & $\begin{array}{c}\text { Small molecular } \\
\text { Intranasal reduced glutathione }\end{array}$ & Reduced glutathione & $\begin{array}{l}\text { PD (Hoehn and } \\
\text { Yahr stage 2-3) }\end{array}$ & Phase I & Not applicable & $\begin{array}{l}\text { University of } \\
\text { Washington }\end{array}$ & NCT02324426 \\
\hline Others & $\begin{array}{l}\text { Small molecular } \\
\text { Synthetic oligopeptide }\end{array}$ & GM 608 & $\begin{array}{c}\text { Mild to } \\
\text { moderate-stage PD }\end{array}$ & Phase II & Not applicable & $\begin{array}{c}\text { Genervon } \\
\text { Biopharmaceuticals, } \\
\text { LLC }\end{array}$ & NCT01850381 \\
\hline Others & $\begin{array}{l}\text { Small molecular } \\
\text { Glucagon-like peptide } 1 \\
\text { receptor agonist }\end{array}$ & NLY01 & Early stage PD & Phase II & Not applicable & Neuraly, Inc. & NCT04154072 \\
\hline
\end{tabular}




\subsection{Convalescent Plasma Therapy}

Plasma contains antibodies, protein complexes, salts, and organic compounds. Therefore, plasma therapy has emerged as one of the safe and well-tolerated PD treatments [58]. It is well-known that infusion of the young plasma reduces $\alpha$-synuclein and Lewy bodies. We found a phase I clinical trial study developing by Stanford University using the transfusion of young plasma (1 unit, twice a week for four weeks) into 15 moderate-stage PD patients (Table 2) (NCT02968433). The trial results show that young fresh frozen plasma was safe, feasible, well-tolerated in PD patients, with no serious adverse events, and the most common adverse effects were mild skin reactions during infusions [58]. In addition, the data showed young plasma maintained improvements in phonemic fluency and the stigma subscore of the PDQ-39 and reduced peripheral TNF- $\alpha$ [58].

$\alpha$-Synuclein aggregation is not the only cause for PD progression; multiple factors are associated with the disease; hence plasma therapy may show limited effects [59]. Nevertheless, plasma therapy also causes health risks such as allergic reactions, breathing difficulties, infection to human immunodeficiency virus (HIV), hepatitis B or hepatitis C virus, or even may cause infection with unknown viruses $[58,60]$.

\subsection{Cell-Based Therapy}

Cell therapy involves the introduction of dopamine-producing cells into the brain via transplantation. Cell-based therapy is a sustainable option that can reduce neurological inflammation in PD [61]. Spheramine (BAY86-5280) is a human retinal cultured epithelial pigment that produces levodopa [62]. In a phase II trial, 35 PD patients were transplanted spheramine (325,000 cells/side) into the post-commissural putamen by micro-carrier in 36 PD patients who underwent sham surgery (Table 2) (NCT00206687). The result showed spheramine did not have significant anti-parkinsonism effects (change in mean motor scores did not differ significantly between groups) [62]. In this trial, 2 and 7 patients died in the sham surgery and spheramine transplantation group, respectively [62]. Porcine choroid plexus produces several neurotrophins and can be safely delivered to the striatum in an encapsulated formulation to protect them from immune attack [63]. NTCELL is an alginate-coated capsule containing clusters of neonatal porcine choroid plexus cells [64]. In 2013, Living Cell technologies hosted a phase I/II trial of NTCELL implantation (Table 2). The trial status shows it was completed on 4 June 2020, and no published data are available (NCT01734733). The phase II trial results showed intra-striatal NTCELL implantation was safe and well-tolerated without change in Unified PD Rating Scale (UPDRS) motor scores for 26 weeks post-intervention compared with baseline (Table 2) (NCT02683629) [63]. In cell-based therapies, embryonic dopamine cell implant surgery entered into phase III trials by the University of Colorado Denver (Table 2) (NCT00038116). The published data of the embryonic dopamine cell surgery revealed that it benefits in reversing severe PD symptoms in younger patients, but not in older patients [65-73]. Neuronal progenitor stem cells are collected from the adult human brain to treat PD, Alzheimer's disease, and multiple sclerosis by Rajavithi Hospital (Thailand) (NCT00927108). Recent information on the neuronal progenitor stem cell therapy clinical trial shows withdrawn by Rajavithi Hospital for unspecific reasons (NCT00927108). In cell therapy, the spheramine, and neuronal progenitor stem cells were discontinued from phase II. NTCELL and embryonic dopamine cell implant methods showed safety and tolerability against PD and could be effective. However, cell therapies may also cause immunosuppression and genetic changes that lead to genetic overexpression or carcinoma; or the treatment may be less effective with a higher risk of non-motor expressions depending on the patient [74].

\subsection{Gene Therapy}

Gene therapy for PD treatment includes genetically engineered therapeutic genes that actively replace, knockout, or correct the faulty genes in PD patients [75]. Various serotypes of non-replicating genetically engineered viral vectors, such as an adeno-associated virus (AAV) or lentivirus, have been applied in gene therapy [76]. Gene therapy can prevent 
dopaminergic neuronal death in the brain [77]. In PD, gene therapies mainly aim to increase the stimulation of neurotrophic action in the brain to improve motor balance in patients [78]. Besides, regulation of glucocerebrosidase levels by gene therapy is one potential therapeutic approach in treating PD [79].

We observed six clinical trials (five gene therapies and one small molecular) that use gene therapy for PD treatment, such as AAV2-GDNF, AAV-GAD, CERE-120 (2 trials), PR001A, and GZ/SAR402671. Presently, AAV2-GDNF (adeno-associated virus serotype 2 borne glial cell line-derived neurotrophic factor) is in a non-randomized open-label safety trial developing for PD treatment by Brain Neurotherapy Bio, Inc. (Table 2). In this phase I trial, they transfer AAV2-GDNF into putamen; the trial status shows under subject recruitment, no published data available (NCT04167540). In a phase I trial, subthalamic nucleus gene transfer by the AAV-GAD (adeno-associated virus borne glutamic acid decarboxylase) indicated safe, well-tolerated, and significant improvements in motor UPDRS scores in 12 advanced PD patients (Table 2) (NCT00195143) [80]. Bilateral stereotactic administration of CERE-120 (AAV2-neurturin) into the substantia nigra was safe and well-tolerated, CERE120 is developing at phase I/II by Sangamo Therapeutics (Table 2) (NCT00985517) [81]. Besides, a piece of news published about the study showed that the treatment failed to improve the patients' difficulties compared to the sham group [82]. Another phase II study of CERE-120 showed no significant difference between the treated and control groups (Table 2) (NCT00400634) [83]. They also observed adverse effects upon treatment with CERE-120 in 13 patients out of 38 total patients [83]. Besides, three of the patients from the CERE-120 treatment developed tumors. Overall, the study data showed no significant improvements compared to the control group [83]. Gene therapy using PR001A targets glucocerebrosidase activity. Preclinical data of PR001A administration also showed diminished $\alpha$-synuclein aggregation and Lewy body levels markedly [84]. The treatment comprises one-time administration of the GBA1 gene (encodes glucocerebrosidase) into the cisterna magna developing by Prevail Therapeutics. The current status of the PR001A phase I/IIa trial shows under subject recruitment, no data available, and is estimated to complete by June 2027 (Table 2) (NCT04127578). GZ/SAR402671 is a small molecular glucocerebrosidase gene mutating therapy in early PD, developing by Genzyme (Table 1). A phase II clinical trial assesses the safety and tolerability of oral GZ/SAR402671 for four weeks compared to placebo controls (NCT02906020). In addition, preclinical data of oral administration of GZ/SAR402671 inhibited lipid accumulation and slowed the progression of $\alpha$-synuclein, ubiquitin, and tau phosphorylation, and enhanced cognitive deficits [53]. GZ/SAR402671 administration was safe and well-tolerated in the phase I trial [53], but the trial has been terminated due to not meeting the primary and secondary endpoints updated on 04 June 2021 (NCT02906020). Overall, the gene therapies targeting the GBA1 gene (PR001A) or neurotrophic factors (AAV-GAD) may be successful in the future. 


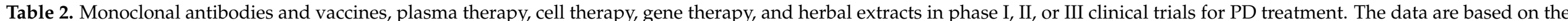
trial status (ongoing, updated, or discontinued) on ClinicalTrials.gov (https:/ / clinicaltrials.gov) that is active as of 16 June 2021.

\begin{tabular}{|c|c|c|c|c|c|c|c|}
\hline Therapeutic Strategy & Classification & Name & PD Subjects & Trial Status & $\begin{array}{c}\text { Reasons for } \\
\text { Discontinuation }\end{array}$ & Sponsor & $\begin{array}{l}\text { ClinicalTrials.gov } \\
\text { Identifier and } \\
\text { Reference }\end{array}$ \\
\hline $\begin{array}{l}\text { Anti- } \alpha \text {-synuclein } \\
\text { aggregation } \\
\text { therapy }\end{array}$ & Monoclonal antibody & ABBV-0805 & Idiopathic PD & $\begin{array}{c}\text { Phase I } \\
\text { discontinued }\end{array}$ & $\begin{array}{l}\text { Withdrawn due to } \\
\text { strategic considerations. }\end{array}$ & AbbVie & NCT04127695 \\
\hline $\begin{array}{l}\text { Anti- } \alpha \text {-synuclein } \\
\text { aggregation } \\
\text { therapy }\end{array}$ & $\begin{array}{c}\text { Vaccine } \\
\text { Short synthetic peptides }\end{array}$ & AFFITOPE ${ }^{\circledR}$ PD01A & Early stage PD & Phase I & Not applicable & Affiris AG & NCT01568099 [45] \\
\hline $\begin{array}{l}\text { Anti- } \alpha \text {-synuclein } \\
\text { aggregation } \\
\text { therapy }\end{array}$ & $\begin{array}{l}\text { Monoclonal antibody } \\
\mathrm{IgG}_{1} \text { protein produced from } \\
\text { memory B cells }\end{array}$ & BIIB054 & PD patients & $\begin{array}{c}\text { Phase II } \\
\text { discontinued }\end{array}$ & $\begin{array}{c}\text { Terminated due to lack } \\
\text { of efficacy. }\end{array}$ & Biogen & NCT03318523 \\
\hline $\begin{array}{l}\text { Anti- } \alpha \text {-synuclein } \\
\text { aggregation } \\
\text { therapy }\end{array}$ & Monoclonal antibody & $\begin{array}{c}\text { PRX002 (Prasinezumab/ } \\
\text { RO7046015) }\end{array}$ & Idiopathic PD & Phase I & Not applicable & $\begin{array}{c}\text { Prothena Biosciences } \\
\text { Limited }\end{array}$ & NCT02157714 [43] \\
\hline $\begin{array}{l}\text { Anti- } \alpha \text {-synuclein } \\
\text { aggregation } \\
\text { therapy }\end{array}$ & Monoclonal antibody & $\begin{array}{c}\text { PRX002 (Prasinezumab / } \\
\text { RO7046015) }\end{array}$ & Early stage PD & Phase II & Not applicable & Hoffmann-La Roche & NCT03100149 [43] \\
\hline $\begin{array}{l}\text { Convalescent plasma } \\
\text { therapy }\end{array}$ & Young plasma infusions & $\begin{array}{c}\text { Infusions of } \\
\text { young plasma }\end{array}$ & Moderate-stage PD & Phase I & Not applicable & Stanford University & NCT02968433 [58] \\
\hline $\begin{array}{l}\text { Cell-based } \\
\text { therapy }\end{array}$ & $\begin{array}{c}\text { Xenotransplantation of } \\
\text { immunoprotected } \\
\text { (alginate-encapsulated) } \\
\text { choroid plexus cells in the } \\
\text { brain }\end{array}$ & NTCELL & Idiopathic PD & Phase I/II & Not applicable & $\begin{array}{l}\text { Living Cell } \\
\text { Technologies }\end{array}$ & NCT01734733 \\
\hline $\begin{array}{l}\text { Cell-based } \\
\text { therapy }\end{array}$ & $\begin{array}{l}\text { Xenotransplantation of } \\
\text { immunoprotected } \\
\text { (alginate-encapsulated) } \\
\text { choroid plexus cells in the } \\
\text { brain }\end{array}$ & NTCELL & Idiopathic PD & Phase II & Not applicable & $\begin{array}{l}\text { Living Cell } \\
\text { Technologies }\end{array}$ & NCT02683629 \\
\hline
\end{tabular}


Table 2. Cont.

\begin{tabular}{|c|c|c|c|c|c|c|c|}
\hline Therapeutic Strategy & Classification & Name & PD Subjects & Trial Status & $\begin{array}{c}\text { Reasons for } \\
\text { Discontinuation }\end{array}$ & Sponsor & $\begin{array}{l}\text { ClinicalTrials.gov } \\
\text { Identifier and } \\
\text { Reference }\end{array}$ \\
\hline $\begin{array}{l}\text { Cell-based } \\
\text { therapy }\end{array}$ & $\begin{array}{l}\text { Neuronal progenitor stem } \\
\text { cells }\end{array}$ & $\begin{array}{l}\text { Adult neuronal } \\
\text { progenitor stem cell }\end{array}$ & PD & $\begin{array}{c}\text { Phase II } \\
\text { discontinued }\end{array}$ & $\begin{array}{l}\text { The study was } \\
\text { withdrawn before } \\
\text { participants were } \\
\text { enrolled. }\end{array}$ & Rajavithi Hospital & NCT00927108 \\
\hline $\begin{array}{l}\text { Cell-based } \\
\text { therapy }\end{array}$ & $\begin{array}{l}\text { Embryonic dopamine cell } \\
\text { implant }\end{array}$ & $\begin{array}{c}\text { Embryonic } \\
\text { dopamine cell } \\
\text { implant surgery }\end{array}$ & Idiopathic PD & Phase III & Not applicable & $\begin{array}{c}\text { University of Colorado, } \\
\text { Denver }\end{array}$ & NCT00038116 [73] \\
\hline Gene therapy & $\begin{array}{l}\text { Surgical infusion of } \\
\text { AAV-GAD into the } \\
\text { subthalamic nucleus }\end{array}$ & $\begin{array}{c}\text { Glutamic acid } \\
\text { decarboxylase }(G A D) \\
\text { gene therapy }\end{array}$ & Advanced-stage PD & Phase I & Not applicable & Neurologix, Inc. & NCT00195143 [80] \\
\hline Gene therapy & $\begin{array}{l}\text { Adeno-associated virus } \\
\text { delivery of neurturin gene } \\
\text { in the substantia nigra and } \\
\text { putamen }\end{array}$ & CERE-120 & Idiopathic PD & Phase I/II & Not applicable & Sangamo Therapeutics & NCT00985517 [81] \\
\hline Gene therapy & $\begin{array}{l}\text { AAV2-neurturin gene } \\
\text { therapy }\end{array}$ & CERE-120 & Idiopathic PD & Phase II & Not applicable & $\begin{array}{c}\text { Sangamo Therapeutics } \\
\text { (Ceregene) }\end{array}$ & NCT00400634 [83] \\
\hline $\begin{array}{l}\text { Antioxidants and } \\
\text { botanical-based } \\
\text { medication }\end{array}$ & $\begin{array}{l}\text { Plant-based herbal dry } \\
\text { powder }\end{array}$ & Hypoestoxide & $\mathrm{PD}$ & Phase I/II & Not applicable & $\begin{array}{l}\text { Adesola Ogunniyi, } \\
\text { University of Ibadan }\end{array}$ & NCT04858074 \\
\hline $\begin{array}{l}\text { Antioxidants and } \\
\text { botanical-based } \\
\text { medication }\end{array}$ & Plant-based herbal extract & WIN-1001X & Early stage PD & Phase II & Not applicable & Medi Help Line & NCT04220762 \\
\hline
\end{tabular}


In gene therapy, delivering the desired gene by a suitable vector into the specific brain area is a sensitive and complicated task. For instance, AAV-based vectors have a limited capacity of 4.7-kb, which prohibits the integration of multiple genes [85]. Several risk factors of gene therapy include impaired gait, dorsal root ganglia, ataxia, and increased transaminases [86,87]. In some cases, the overexpression of the transgene may cause severe toxicity to the targeted organs or tissues $[86,87]$.

\subsection{Serotonin Receptor Agonists or Antagonists}

Motor activities, depression, cognitive and autonomic functions are regulated by the serotonergic neurotransmission system [88]. Therefore, drugs targeting serotonergic receptors modulate behavioral qualities and improved motor balances [89]. We found three clinical trials use serotonin receptor agonists (piclozotan and sarizotan) or antagonists (SYN120) for PD treatment. Piclozotan (SUN N4057) is a selective $5-\mathrm{HT}_{1 \mathrm{~A}}$ receptor agonist developing at phase II by Daiichi Sankyo, Inc. A preclinical study showed that serotonin 1A receptor agonists piclozotan ameliorate motor performances in 6-hydroxydopamineinduced models [90]. The trial status shows it completed subject recruitment while results show no serious adverse events compared to the placebo cohort. However, the piclozotan treatment produced few minor adverse events such as headache, nausea, dizziness, and hypertension (Table 1) (NCT00623363). Preclinical literature also showed that sarizotan benefits in reducing dyskinesia, respiratory problems [91]. Sarizotan possesses serotonin receptor partial agonist and dopamine $\mathrm{D}_{2}$ receptor agonist activities, developing at phase III by EMD Sereno. The status of this trial shows no results (Table 1) (NCT00105508). A study shows that $2 \mathrm{mg} /$ day sarizotan administration had no improvements in dyskinesia compared to placebo subjects [54]. SYN120 is a dual 5- $\mathrm{HT}_{6 / 5}-\mathrm{HT}_{2}$ serotonin receptor antagonist. An update from the American Academy of Neurology's 2019 annual meeting (on 15 May 2019) declared that the SYN120 (SYNAPSE) trial in phase II studied with 80 patients has failed to improve cognitive performance (Table 1) (NCT02258152) [92].

Moreover, not all the serotonin receptor agonists are active/control in mediating the $\mathrm{PD}$. In addition, some of the $5-\mathrm{HT}_{2 \mathrm{~B}}$ receptor agonists reported offering adverse effects; for instance, fenfluramine, pergolide, and cabergoline were discontinued from the pharmaceutical industry due to cardiac fibrosis [93].

\subsection{Monoamine Reuptake Inhibitors}

Pathogenesis of PD is associated with oxidative stress and monoamine oxidase-B activities in the glia of the brain [94]. Monoamine reuptake inhibitors prevent the reuptake of dopamine, serotonin, norepinephrine, and periphrastically. Together these events further activate the cholinergic system that represents potential PD therapeutic targets [95]. We found a clinical trial that uses a monoamine reuptake inhibitor (NS 2330) for PD treatment. NS 2330 (tesofensine) is a triple monoamine reuptake inhibitor. It inhibits the reuptake of cholinergic molecules of dopamine, serotonin, and norepinephrine. These cellular events indirectly stimulate the cholinergic system [96]. Presently, NS 2330 is developing at phase II by Boehringer Ingelheim. For this trial, they recruited 261 subjects with $P D<5$ years that were not receiving dopaminergic treatment and randomly assigned them to daily with NS 2330 at $0.25 \mathrm{mg}, 0.5 \mathrm{mg}, 1.0 \mathrm{mg}$, or placebo (Table 1) (NCT00148486) [97]. Hauser et al.'s (2007) clinical trial data showed that NS 2330 treatment did not affect the total UPDRS score compared to placebo subjects during the fourteen-week experimental period [97]. Besides, the NS 2330 data were not shown to alter parkinsonian signs or dyskinesia when infused with levodopa [98].

\subsection{Muscarinic and Nicotinic Acetylcholine Receptor Agonists}

Cholinergic receptors contain muscarinic receptors (sensitive to muscarine) and nicotinic receptors (sensitive to nicotinic); they function in somatic and autonomic signal transductions in the nervous system [99]. We observed three trials that use muscarinic or nicotinic acetylcholine receptor agonists (Table 1). ANAVEX2-73 is a small molecule that 
binds to muscarinic acetylcholine and sigma1 (s1) receptors in the low micromolar range developing by Anavex Life Sciences Corp [100]. In October 2019, they started a phase II open-label extension to evaluate the effects of ANAVEX2-73 in 120 PD subjects with dementia on the safety and efficacy of daily treatment (Table 1) (NCT04575259). Anavex Life Sciences Corp. estimates the study completion by 31 October 2021. Nicotine is used in two phase-II trials as a transdermal patch (in 2012) and a nasal spray (in 2019) for PD treatment. Unfortunately, the trial data for the nicotine transdermal patch (7 or $14 \mathrm{mg}$ for 52 weeks) in PD patients is unavailable (Table 1) (NCT01560754). Another trial using nicotine nasal spray trial status shows complete under subject recruitment and no results posted (Table 1) (NCT03865121). Although the high doses of transdermal nicotine were also tolerated, they failed to show significant improvements in UPDRS scores [101].

Moreover, the cholinergic drug treatment disadvantages might be less efficient than dopamine receptor agonists or carbidopa-levodopa treatment or even may cause adverse effects on parasympathetic nerve-related organs in PD [102].

\subsection{N-Methyl-D-Aspartate Receptor (NMDAR) Modulators}

In addition to the dopaminergic neuronal loss in PD, dysregulation of NMDAR in the cortical-striatal-pallidal-thalmo-cortical network and changes in plasticity of the brain regions are also crucial for cognitive function [103]. NMDAR modulators enhance synaptic plasticity [103]. We observed two trials in phase II that use NMDA receptor modulators (NYX-458 and DAAOI-P) in the PD treatment (Table 1). NYX-458 is an NMDAR modulator that increases cognitive properties and synaptic plasticity [103,104]. NYX-458 phase II trial plans to recruit PD subjects with mild cognitive impairments; the trial status shows the active recruiting and is estimated to complete by 22 December 2022 (NCT04148391). DAAOI-P (Flavoenzyme) is a D-amino acid oxidase inhibitor that facilitates the NMDA receptor subunit-1 and catalyzes/degrades D-amino acids by oxidative deamination in PD dementia developing by China Medical University Hospital (Taiwan). The phase II trial status of DAAOI-P in PD subjects with dementia shows under recruitment, and no published data is available; the trial is estimated to complete by July 2022 (NCT04470037).

NMDAR modulators also showed adverse effects such as irregular heartbeats, nausea, vomiting, psychosis, catalepsy, constipation, analgesia, and amnesia $[105,106]$.

\subsection{Anti-Apoptotic Drugs}

During PD progression, degeneration of neurons occurs due to apoptosis and necrosis [19]. We observed two clinical trials that use small molecule anti-apoptotic drugs, i.e., TCH346 and minocycline. TCH346 is also known as dibenz[b,f]oxepin-10-ylmethyl-prop2-ynyl-amine hydrogen maleate salt. TCH346 is undergoing phase I/II clinical trial in 301 early-stage PD patients, and it is developing by Novartis; the trial status shows it is complete, and no published data are available (Table 1) (NCT00407212). Preclinical data showed that TCH346 protected from dopaminergic neuronal damage [107]. Minocycline is a neuroprotective synthetic tetracycline derivative that mainly targets anti-apoptotic pathways; it modulates microglial cells and reduces oxidative stress and neuroinflammation [108]. Minocycline treatment ( $200 \mathrm{mg} /$ day) has completed the phase II clinical trial in 66 subjects with early untreated PD patients (Table 1) (NCT00063193). The published trial data showed that the mean changes in total UPDRS scores for minocycline were not significantly different in PD treatment [55].

\subsection{Kinase Inhibitors}

LRRK2 kinase activities and their effects in PD enhance the degeneration of disease progression; LRRK2 inhibition offers neuroprotection in PD [109]. We identified two clinical trials that use small molecule kinase inhibitors (CEP-1347 and K0706). CEP-1347 (KT7515) is a semisynthetic inhibitor of the mixed lineage kinase family; it promotes neuronal survival by inhibiting c-Jun amino-terminal kinases (JNKs) activation [110]. CEP-1347 was in phase II/III trial and was terminated by Cephalon due to insignificant trial results (Table 1) 
(NCT00040404) [56,111]. The published trial results showed that urate and its determinants caused the disease progression [56]. Moreover, CEP-1347 treatment fails to slower disease progression in early PD patients [111]. K0706 is a potent orally selective inhibitor of cABL protein tyrosine kinase; K0706 exhibits neuroprotective activity [112]. A phase II trial using K0706 was performed by Sun pharma (SPARC) (Table 1). The trial status of K0706 in early PD subjects shows under subject recruitment with no results posted and is estimated to be completed by March 2023 (NCT03655236).

Kinase inhibitors may also cause side effects such as fatigue, diarrhea, hypertension, abnormal wound healing or rashes, periorbital edema, and myelosuppression $[113,114]$.

\subsection{Myeloperoxidase Inhibitors}

Mitochondrial dysfunction, oxidative stress, and the formation of excessive reactive oxygen species are involved in the progress of PD neurodegeneration [115]. Myeloperoxidase inhibition reduces the production of reactive oxygen species and further neuroinflammation in PD [116]. We found a clinical trial that uses AZD3241 as a myeloperoxidase inhibitor. It is an irreversible myeloperoxidase inhibitor and was found to be safe without serious adverse events; the common side effects are nausea, headache, nasopharyngitis, insomnia, and weakness [115]. AZD3241 undergoes a phase II clinical trial (300 or $600 \mathrm{mg}$, two times a day for 12 weeks) in 51 PD subjects (by AstraZeneca). The trial status shows complete, and no published data is available (Table 1) (NCT01603069). Jucaite et al. (2015) showed that administration of AZD3241 (at $600 \mathrm{mg}$ twice a day for eight weeks) inhibited 11C-PBR28 binding to the translocator proteins (a hallmark of microglial activation) and inflammation in the PD patients and might be effective against myeloperoxidation in PD [115].

\subsection{Adenosine $A_{2 A}$ Receptor Antagonists}

Adenosine receptors are promising therapeutic targets for a variety of diseases, including PD [117]. We found two clinical trials that use adenosine $A_{2 A}$ receptor antagonists (V81444 and caffeine). The V81444 is a small molecular drug for PD treatment in phase I clinical trial, developing by Vernalis (R\&D) Ltd., Kansas, United States (Table 1). The trial status shows completed in subject recruiting, and the result is unavailable (NCT02764892). Moreover, the Vernalis (R\&D) patented V81444 for further trials and commercialization of the drug [118]. Caffeine acts as a selective adenosine $\mathrm{A}_{2 \mathrm{~A}}$ receptor antagonist (due to its xanthine property) [119] and reduces neurotoxicity by blocking $\mathrm{A}_{2 \mathrm{~A}}$ receptors [120]. In 2014, McGill University Health Centre performed the phase III trial of caffeine for PD treatment (Table 1) (NCT01738178). The trial result shows that caffeine did not provide clinically efficient improvement of motor manifestations in $60 \mathrm{PD}$ patients [57]. Based on the available data, V81444 might be an effective Adenosine $\mathrm{A}_{2 \mathrm{~A}}$ antagonist compared to caffeine treatment. However, the epidemiologic links between caffeine and lower PD risk do not appear to be explained by symptomatic effects [57].

\subsection{Antioxidants and Botanical-Based Medication}

The free radical scavenging activity of antioxidants is the major contributor to the protection of dopaminergic neurons and improved mitochondrial functions in sporadic and hereditary PD [121]. Mitochondrial dysfunction is associated with PD pathogenesis; free radical scavenging activity eliminates damaged mitochondria by mitophagy and provides neuroprotection in PD [122]. The decrease of reduced glutathione in the PD brain is one of the pathogenic hallmarks of neuroinflammation [123]. It indicates the importance of reduced glutathione therapy against the oxidation of neurons in the PD treatment. Intranasal application of reduced glutathione (tripeptide glutathione) is a new method of administration used in the antioxidant treatment. We found two clinical trials that use intranasal glutathione as antioxidant therapy for PD treatment in phase I. The status of intranasal glutathione therapy for thirty-four PD subjects shows it is complete without results (NCT01398748). In addition, the trial status of intranasal reduced glutathione 
therapy for 15 PD subjects also shows it is complete without trial results (NCT02324426). The reduced glutathione treatment modulates the excessive free radical formation and inhibits neuroinflammation in PD [124].

In herbal extract treatment, we observed two clinical trials (Win-1001X and hypoestoxide) for PD treatment. Win-1001X is a plant-based herbal extract for PD treatment in phase II, developing by Medi Help Line. Win-1001X contains the extracts of three plants, for instance, Angelica tenuissima Nakai, Dimocarpus longan (L.), and Polygala tenuifolia. Kim et al. (2014) revealed that Win-1001X increased LC3-II/I, DOR, and GATE16 autophagy-related protein expressions in the midbrain and rescued neuronal damage in rodents [125]. Furthermore, they showed that Win-1001X extract mainly targets autophagy and antioxidant mechanisms and reduced neuroinflammation [125]. This clinical trial used WIN-1001X (400, 800, and $1200 \mathrm{mg}$ ) to treat early PD patients (Table 2) (NCT04220762). However, the trial status of WIN-1001X therapy shows subject recruitment with no posted results (NCT04220762). Hypoestoxide is a natural active diterpene phytochemical constituent of Hypoestes rosea that acts against PD progression and cancer [126]. Ojo-Amaize and Cottom, (2016) revealed that hypoestoxide offers several beneficial effects in inhibiting the activity of IкB, NFkB, and other inflammatory pathways and modulate PD features [126]. Hypoestoxide is undergoing phase I/II clinical trial for PD by Adesola Ogunniyi, University of Ibadan (Table 2) (NCT04858074). Besides, preclinical data also showed improvements in motor symptoms and lowered disease progression of PD [127].

However, the advantages of herbal extract treatment include no serious adverse events and long-term benefits in disease management compared to modern medicine.

\subsection{Others}

We found two phase-II clinical trials that use other types of drugs for the PD treatment, i.e., GM 608, and NLY01. GM 608 is a motoneuronotrophic endogenous embryonic neural regulatory and signaling peptide (synthetic oligopeptide) developing by Genervon Biopharmaceuticals, LLC. GM 608 has neuroprotection and regulates the development of the human nervous system [128]. The status of the GM 608 phase II trial shows completed in subject recruitment, but no published data is available (Table 1) (NCT01850381). NLY01 is a novel exenatide-based compound developing by Neuraly Inc. [129]. The NLY01 is a pegylated form of exendin-4 (exenatide), which binds to glucagon-like peptide-1 receptors (GLP-1R) and expresses in glial brain cells [129]. Studies of NLY01 in PD showed that NLY01 limited neuronal death decreased formation of an inflammatory cascade and neurotoxic astrocytes, and partial motor function decline [129]. NLY01 is in a phase II trial; the status is under recruitment which is developing by Neuraly, and they estimate to complete it by December 2022 (Table 1) (NCT04154072).

\section{Discussion}

The incidence of PD is increasing with age; the PD patient number may be doubled worldwide by 2040 [130]. Still, there is no permanent cure available for PD patients [122]. Additionally, no clear diagnostic method exists to evaluate the PD [131]. Therefore, it is important to search for the mechanisms or diagnosis/screening of PD. Preclinical data are exceedingly important for every human clinical trial [132]. Preclinical studies involve a wide range of studies (in vitro or in vivo) for the safety, toxicity, and mechanisms of the PD and provide information on dosage safety and potential toxicity. Several preclinical in vitro or in vivo investigations effectively reduced or protected from the PD symptoms, but most of them are not yet tested on humans, or some failed when tested in humans [19]. Even though levodopa treatment is a gold standard to improve PD symptoms, levodopa has no neuroprotection [133]. Levodopa therapy will become ineffective after 5 years of usage in PD patients [34]. Combination therapy has emerged as an alternative therapy and has shown greater benefits than monotherapy [134]. In PD, reducing the dose of levodopa and its use combined with other drugs temporarily benefits motor symptoms (for instance, dopamine agonists or monoamine oxidase-B inhibitors). Drugs such 
as levodopa, carbidopa, monoamine oxidase-B inhibitors, catechol-O-methyl transferase inhibitors, apomorphine were established over 3-5 decades ago [134-136]. Drug combinations (carbidopa-levodopa and carbidopa-entacapone-levodopa) are used for PD treatment, but the drug combination is expensive [137]. Duodopa, a micro-suspension gel of levodopa and carbidopa used for continuous stimulation of dopaminergic cells in PD patients, costs over USD 35,000/year/patient [9]. Several non-pharmacologic surgical treatments are also available, such as deep brain stimulation (DBS) and focused ultrasound therapy [138-141]. DBS treatment is used in patients with severe motor symptoms who are unresponsive to levodopa and carbidopa therapy for a minimum of 4 years [138-141]. DBS involves implanting electrodes in the patient's brain to improve PD motor symptoms; DBS risks include brain hemorrhage, device malfunction, infection, and mental illness with side effects such as imbalance, impaired vision, or vocal problems [138-141]. Moreover, the actual underlying mechanisms of DBS treatment are not yet known [142]. Additionally, DBS is expensive at about USD 50,000/patient, which is not affordable for all PD patients in low or middle-income countries [143].

Although the dopamine receptor agonists play an important role in PD symptomatic treatment, prolonged usage of dopamine receptor agonists causes side effects such as drowsiness, illusions, orthostatic hypotension, compulsive eating, weight gain, and edema [144-146]. Besides, studies showed that long-term usage of dopamine receptor agonists in PD patients caused several psychotic behavioral side effects such as gambling behavior and hypersexuality $[147,148]$. The adverse effects are dose-dependent and may sensitize/damage the dopaminergic receptors in the basal ganglia permanently [149]. In addition, physicians should be aware that compulsive eating resulting in significant weight gain may occur in PD as a side-effect of dopamine agonist medications such as pramipexole [144].

Lewy body dementia is the most common hallmark of neurodegenerative diseases. Chia et al. (2021) performed whole-genome sequencing in controls and Lewy body dementia cases (Alzheimer's and Parkinson's diseases) to find out the genetic architecture [150]. Their study revealed that GBA1, BIN1, TMEM175, SNCA-AS1, and APOE loci are responsible for increases in Lewy body pathogenesis [150]. PD is a multigene risk associated with multiple-genetic changes. Nevertheless, recent studies showed that gene therapy also causes several adverse effects such as undesirable immune system reactions, inflammation, organ failure, and cancer [151].

Health risks of plasma transfusions include HIV, hepatitis C, or hepatitis B viral infections [152,153]. To avoid such risks, donor rested plasma or pathogen reduced plasma are safer [154]. Donor rested plasma is safe due to quarantine (subsequent donations) and tests for infectious diseases $[154,155]$. In addition, pathogen-reduced plasma is also safe; it increases protection from lipid-enveloped viruses $[154,156]$. However, plasma therapy also can cause risks associated with non-enveloped viral infections (e.g., hepatitis A, parvovirus B19) and prion diseases [157]. Several IVIG injected cases acquired acute hepatitis in the United States, Europe, Norway, and Puerto Rico [158]. Moreover, stored plasma is also a risk factor in plasma therapy; for instance, few previous cases also found bacterial infections of Pseudomonas, Staphylococcus, Klebsiella, Providencia rettgeri, and Propionibacterium, or even it may cause a risk of immune suppression [159].

In the present review, we found 293 PD clinical trials on ClinicalTrials.gov (active as of 16 June 2021). Next, we shortlisted forty-seven clinical trials as novel PD drugs or therapies (excluded levodopa/carbidopa/add-on therapies). Among them, 19 trials are in phase I (41\%), 25 clinical trials are in phase II (53\%), and 3 trials are in phase III (6\%). The PD therapeutic strategy of each clinical trial shows 29, 5, 1, 5, 5, and 2 clinical trials use small molecules, monoclonal antibodies, plasma therapy, cell therapies, gene therapies, and herbal extracts, respectively. The majority of PD clinical trials use small molecular drugs (29 clinical trials, $61.7 \%$ ), but most of them are monotherapy, not multi-target. All the therapeutic strategies in these clinical trials are divided into 15 types, based on the type of drug/therapy. These 15 types include (1) dopamine receptor agonists: 6 trials, (2) anti- $\alpha$-synuclein aggregation therapy: 7 trials, (3) convalescent plasma therapy: 1 trial, 
(4) cell-based therapy: 5 trial, (5) gene therapy: 6 (5 gene therapy and 1 small molecular glucosylceramide synthase inhibitor) (6) serotonin receptor agonists or antagonists: 3 trials, (7) muscarinic and nicotinic acetylcholine receptor agonists: 3 trials, (8) monoamine reuptake inhibitors: 1 trial, (9) NMDAR modulators: 2 trials, (10) anti-apoptotic drugs: 2 trials, (11) kinase inhibitors: 2 trials, (12) myeloperoxidase inhibitors: 1 trial, (13) adenosine $A_{2 A}$ receptor antagonists: 2 trials, (14) antioxidants/botanical-based medication: 4 trials, and (15) others: 2 trials (Figure 5).

Drug discovery is an expensive, slow, and risky business. The overall failure rate in drug development is more than $96 \%$, in which $90 \%$ fail during clinical development [160]. From the forty-seven clinical trials in the present study, 44 trials (94\%) are in phase I for safety and dosage evaluations or phase II for efficacy and side effect assessments. Only three trials $(6 \%)$ in phase III are active (embryonic cell implant surgery, sarizotan, and caffeine) for efficacy and adverse effect monitoring. It indicates the need for more drugs in clinical trials for PD treatment. In addition, the available medication or treatment is not affordable for low/middle-income people. The cost of PD medications alone is around $\$ 5853.50$ USD/patient/year in Brazil, and DBS is around \$186,244 USD/patient/5-years [161].

According to Parkinson's Foundation, about 10-million people worldwide live with PD, and PD incidence increases with age [162]. The disease progression and symptoms of $\mathrm{PD}$ are unique from one patient to another, and their medications are decided based on the disease progression and symptoms of each patient. Overall, the review highlights the current treatments for PD in clinical trials updated as of 16 June 2021. However, the low success rate of curable PD drugs, and high PD incidence, alarming the need to discover multi-target or combined (disease-modification/neuroprotective) medications for the PD.

\section{Conclusions}

In conclusion, the treatments that use small molecule $\alpha$-synuclein aggregation therapy (ambroxol or $\mathrm{Cu}$ (II)ATSM) or monoclonal antibody (AFFITOPE ${ }^{\circledR}$ PD01A, and PRX002) or gene therapy (PR001A/AAV-GAD) might be promising compared to other clinical trials/therapies for the treatment of PD in future. In our view, the aim of the clinical trials should delay motor complications in later stages that may show long-lasting complications. However, with the rapid rise of the rate of PD incidence worldwide, finding new multitarget drugs or therapies without adverse reactions is a huge challenge.

Author Contributions: E.M.P. and S.-Y.H. wrote the manuscript. S.-Y.H. supervised and revised the final version of the manuscript. Both authors have read and agreed to the published version of the manuscript.

Funding: This work was supported by grants from the Ministry of Science and Technology of Taiwan (MOST 109-2811-B-039-518 and MOST 108-2320-B-039-029-MY3) and China Medical University (CMU108-MF-39), Taiwan.

Institutional Review Board Statement: Not applicable.

Informed Consent Statement: Not applicable.

Data Availability Statement: Not applicable.

Conflicts of Interest: The authors have no financial disclosures or conflicts of interest to declare.

\section{References}

1. Marino, S.; Ciurleo, R.; Di Lorenzo, G.; Barresi, M.; De Salvo, S.; Giacoppo, S.; Bramanti, A.; Lanzafame, P.; Bramanti, P. Magnetic resonance imaging markers for early diagnosis of Parkinson's disease. Neural Regen. Res. 2012, 7, 611-619. [CrossRef] [PubMed]

2. Dauer, W.; Przedborski, S. Parkinson's disease: Mechanisms and models. Neuron 2003, 39, 889-909. [CrossRef]

3. Rabinstein, A.A.; Shulman, L.M. Management of behavioral and psychiatric problems in Parkinson's disease. Parkinsonism Relat. Disord. 2000, 7, 41-50. [CrossRef]

4. Horstink, D.M.W.I.M. Parkinson's disease and parkinsonism in the elderly. Brain 2000, 123, 2569-2571. [CrossRef]

5. Boxall, J. Early onset Parkinson's disease. Part 2: Physician's viewpoint. Can. Fam. Phys. 1994, 40, 513-515. [PubMed] 
6. Foltynie, T.; Sawcer, S.; Brayne, C.; Barker, R.A. The genetic basis of Parkinson's disease. J. Neurol. Neurosurg. Psychiatry 2002, 73, 363-370. [CrossRef]

7. Maroteaux, L.; Campanelli, J.T.; Scheller, R.H. Synuclein: A neuron-specific protein localized to the nucleus and presynaptic nerve terminal. J. Neurosci. 1988, 8, 2804. [CrossRef] [PubMed]

8. Maguire-Zeiss, K.A. $\alpha$-Synuclein: A therapeutic target for Parkinson's disease? Pharm. Res. 2008, 58, 271-280. [CrossRef]

9. Abbott, A. Levodopa: The story so far. Nature 2010, 466, S6-S7. [CrossRef]

10. Lesser, R.P.; Fahn, S.; Snider, S.R.; Cote, L.J.; Isgreen, W.P.; Barrett, R.E. Analysis of the clinical problems in parkinsonism and the complications of long-term levodopa therapy. Neurology 1979, 29, 1253-1260. [CrossRef]

11. Guebila, M.B.; Thiele, I. Model-based dietary optimization for late-stage, levodopa-treated, Parkinson's disease patients. NPJ Syst. Biol. Appl. 2016, 2, 16013. [CrossRef] [PubMed]

12. Lieberman, A.; Goodgold, A.; Jonas, S.; Leibowitz, M. Comparison of dopa decarboxylase inhibitor (carbidopa) combined with levodopa and levodopa alone in Parkinson's disease. Neurology 1975, 25, 911. [CrossRef]

13. Kaakkola, S.; Männistö, P.T.; Nissinen, E.; Vuorela, A.; Mäntylä, R. The effect of an increased ratio of carbidopa to levodopa on the pharmacokinetics of levodopa. Acta Neurol. Scand. 1985, 72, 385-391. [CrossRef]

14. Dodd, M.L.; Klos, K.J.; Bower, J.H.; Geda, Y.E.; Josephs, K.A.; Ahlskog, J.E. Pathological gambling caused by drugs used to treat parkinson disease. Arch. Neurol. 2005, 62, 1377-1381. [CrossRef] [PubMed]

15. Wu, J.; Lim, E.-C.; Nadkarni, N.V.; Tan, E.-K.; Kumar, P.M. The impact of levodopa therapy-induced complications on quality of life in Parkinson's disease patients in Singapore. Sci. Rep. 2019, 9, 9248. [CrossRef]

16. Sharma, S.; Singh, S.; Sharma, V.; Singh, V.P.; Deshmukh, R. Neurobiology of 1-DOPA induced dyskinesia and the novel therapeutic strategies. Biomed. Pharmacother. 2015, 70, 283-293. [CrossRef]

17. AlDakheel, A.; Kalia, L.V.; Lang, A.E. Pathogenesis-targeted, disease-modifying therapies in Parkinson disease. Neurotherapeutics 2014, 11, 6-23. [CrossRef] [PubMed]

18. Antonini, A.; Odin, P.; Pahwa, R.; Aldred, J.; Alobaidi, A.; Jalundhwala, Y.J.; Kukreja, P.; Bergmann, L.; Inguva, S.; Bao, Y.; et al. The long-term impact of levodopa/carbidopa intestinal gel on 'off'-time in patients with advanced parkinson's disease: A systematic review. Adv. Ther. 2021, 10. [CrossRef]

19. Prasad, E.M.; Hung, S.Y. Behavioral tests in neurotoxin-induced animal models of parkinson's disease. Antioxidants 2020, $9,7$. [CrossRef]

20. Step 3: Clinical Research. Available online: https://www.fda.gov/patients/drug-development-process/step-3-clinical-research (accessed on 26 January 2021).

21. Velentgas, P.; Dreyer, N.A.; Wu, A.W. Outcome definition and measurement. In Developing a Protocol for Observational Comparative Effectiveness Research: A User's Guide; Agency for Healthcare Research and Quality (US): Rockville, MD, USA, 2013.

22. Merchant, K.M.; Cedarbaum, J.M.; Brundin, P.; Dave, K.D.; Eberling, J.; Espay, A.J.; Hutten, S.J.; Javidnia, M.; Luthman, J.; Maetzler, W.; et al. A proposed roadmap for Parkinson's disease proof of concept clinical trials investigating compounds targeting alpha-synuclein. J. Parkinson's Dis. 2019, 9, 31-61. [CrossRef]

23. Grimes, J.D.; Hassan, M.N.; Thakar, J. Antioxidant therapy in Parkinson's disease. Can. J. Neurol. Sci. J. Can. Des. Sci. Neurol. 1987, 14, 483-487. [CrossRef]

24. Annus, Á.; Vécsei, L. Spotlight on opicapone as an adjunct to levodopa in Parkinson's disease: Design, development and potential place in therapy. Drug Des. Dev. Ther. 2017, 11, 143-151. [CrossRef]

25. Gurevich, E.V.; Gainetdinov, R.R.; Gurevich, V.V. G protein-coupled receptor kinases as regulators of dopamine receptor functions. Pharm. Res. 2016, 111, 1-16. [CrossRef] [PubMed]

26. Beaulieu, J.M.; Gainetdinov, R.R. The physiology, signaling and pharmacology of dopamine receptors. Pharm. Rev. 2011, 63, 182-217. [CrossRef] [PubMed]

27. Undieh, A.S. Pharmacology of signaling induced by dopamine D(1)-like receptor activation. Pharm. Ther. 2010, 128, 37-60. [CrossRef]

28. Ghiglieri, V.; Bagetta, V.; Pendolino, V.; Picconi, B.; Calabresi, P. Corticostriatal plastic changes in experimental L-DOPA-induced dyskinesia. Parkinson's Dis. 2012, 2012, 358176. [CrossRef]

29. Papapetropoulos, S.; Liu, W.; Duvvuri, S.; Thayer, K.; Gray, D.L. Evaluation of D1/D5 partial agonist PF-06412562 in Parkinson's disease following oral administration. Neurodegener. Dis. 2018, 18, 262-269. [CrossRef] [PubMed]

30. Huang, X.; Lewis, M.M.; Van Scoy, L.J.; De Jesus, S.; Eslinger, P.J.; Arnold, A.C.; Miller, A.J.; Fernandez-Mendoza, J.; Snyder, B.; Harrington, W.; et al. The D1/D5 dopamine partial agonist PF-06412562 in advanced-stage Parkinson's disease: A feasibility study. J. Parkinson's Dis. 2020, 10, 1515-1527. [CrossRef] [PubMed]

31. Gurrell, R.; Duvvuri, S.; Sun, P.; DeMartinis, N. A phase I study of the safety, tolerability, pharmacokinetics and pharmacodynamics of the novel dopamine D1 receptor partial agonist, PF-06669571, in subjects with idiopathic Parkinson's disease. Clin. Drug Investig. 2018, 38, 509-517. [CrossRef]

32. Sohur, U.S.; Gray, D.L.; Duvvuri, S.; Zhang, Y.; Thayer, K.; Feng, G. Phase 1 Parkinson's disease studies show the dopamine D1/D5 agonist PF-06649751 is safe and well tolerated. Neurol. Ther. 2018, 7, 307-319. [CrossRef]

33. Riesenberg, R.; Werth, J.; Zhang, Y.; Duvvuri, S.; Gray, D. PF-06649751 efficacy and safety in early Parkinson's disease: A randomized, placebo-controlled trial. Adv. Neurol. Disord. 2020, 13. [CrossRef] [PubMed] 
34. Choi, J.; Horner, K.A. Dopamine agonists. In StatPearls; StatPearls Publishing, Copyright @ 2020; StatPearls Publishing LLC.: Treasure Island, FL, USA, 2020.

35. Merims, D.; Giladi, N. Dopamine dysregulation syndrome, addiction and behavioral changes in Parkinson's disease. Parkinsonism Relat. Disord. 2008, 14, 273-280. [CrossRef]

36. Constantinescu, R. Update on the use of pramipexole in the treatment of Parkinson's disease. Neuropsychiatr Dis. Treat. 2008, 4, 337-352. [CrossRef] [PubMed]

37. Silveira, C.R.A.; MacKinley, J.; Coleman, K.; Li, Z.; Finger, E.; Bartha, R.; Morrow, S.A.; Wells, J.; Borrie, M.; Tirona, R.G.; et al. Ambroxol as a novel disease-modifying treatment for Parkinson's disease dementia: Protocol for a single-centre, randomized, double-blind, placebo-controlled trial. BMC Neurol. 2019, 19, 20. [CrossRef] [PubMed]

38. Fischer, T.; Sardi, S.P.; Shihabuddin, L.; Rudin, D.; Sharma, J.; Araujo, R.; Li, J.; Peterschmitt, M.J. Evaluation of glucosylceramide synthase (GCS) inhibition for GBA-associated Parkinson's disease (P3.051). Neurology 2018, 90.

39. Goetz, C.G.; Laska, E.; Hicking, C.; Damier, P.; Müller, T.; Nutt, J.; Warren Olanow, C.; Rascol, O.; Russ, H. Placebo influences on dyskinesia in Parkinson's disease. Mov. Disord. 2008, 23, 700-707. [CrossRef]

40. Parashos, S.A.; Luo, S.; Biglan, K.M.; Bodis-Wollner, I.; He, B.; Liang, G.S.; Ross, G.W.; Tilley, B.C.; Shulman, L.M. Measuring disease progression in early Parkinson disease: The national institutes of health exploratory trials in Parkinson disease (NET-PD) experience. JAMA Neurol. 2014, 71, 710-716. [CrossRef] [PubMed]

41. Schwarzschild, M.A.; Schwid, S.R.; Marek, K.; Watts, A.; Lang, A.E.; Oakes, D.; Shoulson, I.; Ascherio, A.; Hyson, C.; Gorbold, E.; et al. Serum urate as a predictor of clinical and radiographic progression in Parkinson disease. Arch. Neurol. 2008, 65, 716-723. [CrossRef] [PubMed]

42. Postuma, R.B.; Anang, J.; Pelletier, A.; Joseph, L.; Moscovich, M.; Grimes, D.; Furtado, S.; Munhoz, R.P.; Appel-Cresswell, S.; Moro, A.; et al. Caffeine as symptomatic treatment for Parkinson disease (Café-PD): A randomized trial. Neurology 2017, 89, 1795-1803. [CrossRef]

43. Stefanis, L. $\alpha$-Synuclein in Parkinson's disease. Cold Spring Harb. Perspect. Med. 2012, 2, a009399. [CrossRef]

44. Iwatsubo, T. Aggregation of alpha-synuclein in the pathogenesis of Parkinson's disease. J. Neurol. 2003, 250, iii11-iii14. [CrossRef]

45. Bengoa-Vergniory, N.; Roberts, R.F.; Wade-Martins, R.; Alegre-Abarrategui, J. Alpha-synuclein oligomers: A new hope. Acta Neuropathol. 2017, 134, 819-838. [CrossRef]

46. Fields, C.R.; Bengoa-Vergniory, N.; Wade-Martins, R. Targeting alpha-synuclein as a therapy for Parkinson's disease. Front. Mol. Neurosci. 2019, 12, 299. [CrossRef] [PubMed]

47. Bobela, W.; Aebischer, P.; Schneider, B.L. Alpha-synuclein as a mediator in the interplay between aging and Parkinson's disease. Biomolecules 2015, 5, 2675-2700. [CrossRef]

48. Weihofen, A.; Liu, Y.; Arndt, J.W.; Huy, C.; Quan, C.; Smith, B.A.; Baeriswyl, J.L.; Cavegn, N.; Senn, L.; Su, L.; et al. Development of an aggregate-selective, human-derived $\alpha$-synuclein antibody BIIB054 that ameliorates disease phenotypes in Parkinson's disease models. Neurobiol. Dis. 2019, 124, 276-288. [CrossRef]

49. Jankovic, J.; Goodman, I.; Safirstein, B.; Marmon, T.K.; Schenk, D.B.; Koller, M.; Zago, W.; Ness, D.K.; Griffith, S.G.; Grundman, M.; et al. Safety and tolerability of multiple ascending doses of PRX002/RG7935, an anti- $\alpha$-synuclein monoclonal antibody, in patients with Parkinson disease: A randomized clinical trial. JAMA Neurol. 2018, 75, 1206-1214. [CrossRef] [PubMed]

50. Carvalho, J. Results Set Stage for Phase 2 Trial of Investigational Vaccine Affitope PD01A, Affiris Says. Parkinson's Newws Today, 24 June 2020.

51. McFarthing, K.; Simuni, T. Clinical trial highlights: Targeting alpha-synuclein. J. Parkinson's Dis. 2019, 9, 5-16. [CrossRef]

52. Analogue-based drug discovery. Chem. Int. 2010, 32, 12-15. [CrossRef]

53. Magalhaes, J.; Gegg, M.E.; Migdalska-Richards, A.; Schapira, A.H. Effects of ambroxol on the autophagy-lysosome pathway and mitochondria in primary cortical neurons. Sci. Rep. 2018, 8, 1385. [CrossRef]

54. Mullin, S.; Smith, L.; Lee, K.; D’Souza, G.; Woodgate, P.; Elflein, J.; Hällqvist, J.; Toffoli, M.; Streeter, A.; Hosking, J.; et al. Ambroxol for the treatment of patients with Parkinson disease with and without glucocerebrosidase gene mutations: A nonrandomized, noncontrolled trial. JAMA Neurol. 2020, 77, 427-434. [CrossRef] [PubMed]

55. Hung, L.W.; Villemagne, V.L.; Cheng, L.; Sherratt, N.A.; Ayton, S.; White, A.R.; Crouch, P.J.; Lim, S.; Leong, S.L.; Wilkins, S.; et al. The hypoxia imaging agent $\mathrm{CuII}(\mathrm{atsm})$ is neuroprotective and improves motor and cognitive functions in multiple animal models of Parkinson's disease. J. Exp. Med. 2012, 209, 837-854. [CrossRef] [PubMed]

56. Parker, J.E.; Martinez, A.; Deutsch, G.K.; Prabhakar, V.; Lising, M.; Kapphahn, K.I.; Anidi, C.M.; Neuville, R.; Coburn, M.; Shah, N.; et al. Safety of plasma infusions in Parkinson's disease. Mov. Disord. 2020. [CrossRef] [PubMed]

57. Gross, R.E.; Watts, R.L.; Hauser, R.A.; Bakay, R.A.; Reichmann, H.; von Kummer, R.; Ondo, W.G.; Reissig, E.; Eisner, W.; SteinerSchulze, H.; et al. Intrastriatal transplantation of microcarrier-bound human retinal pigment epithelial cells versus sham surgery in patients with advanced Parkinson's disease: A double-blind, randomised, controlled trial. Lancet Neurol. 2011, 10, 509-519. [CrossRef]

58. Ma, Y.; Tang, C.; Chaly, T.; Greene, P.; Breeze, R.; Fahn, S.; Freed, C.; Dhawan, V.; Eidelberg, D. Dopamine cell implantation in Parkinson's disease: Long-term clinical and (18)F-FDOPA PET outcomes. J. Nucl. Med. 2010, 51, 7-15. [CrossRef]

59. Kaplitt, M.G.; Feigin, A.; Tang, C.; Fitzsimons, H.L.; Mattis, P.; Lawlor, P.A.; Bland, R.J.; Young, D.; Strybing, K.; Eidelberg, D.; et al. Safety and tolerability of gene therapy with an adeno-associated virus (AAV) borne GAD gene for Parkinson's disease: An open label, phase I trial. Lancet 2007, 369, 2097-2105. [CrossRef] 
60. Bartus, R.T.; Baumann, T.L.; Siffert, J.; Herzog, C.D.; Alterman, R.; Boulis, N.; Turner, D.A.; Stacy, M.; Lang, A.E.; Lozano, A.M.; et al. Safety/feasibility of targeting the substantia nigra with AAV2-neurturin in Parkinson patients. Neurology 2013, 80, 1698-1701. [CrossRef]

61. Marks, W.J., Jr.; Bartus, R.T.; Siffert, J.; Davis, C.S.; Lozano, A.; Boulis, N.; Vitek, J.; Stacy, M.; Turner, D.; Verhagen, L.; et al. Gene delivery of AAV2-neurturin for Parkinson's disease: A double-blind, randomised, controlled trial. Lancet Neurol. 2010, 9, 1164-1172. [CrossRef]

62. Ghosh, S.; Won, S.J.; Wang, J.; Fong, R.; Butler, N.J.M.; Moss, A.; Wong, C.; Pan, J.; Sanchez, J.; Huynh, A.; et al. $\alpha$-Synuclein aggregates induce c-Abl activation and dopaminergic neuronal loss by a feed-forward redox stress mechanism. Prog. Neurobiol. 2021, 202, 102070. [CrossRef]

63. Outeiro, T.F. Alpha-Synuclein. In Reference Module in Neuroscience and Biobehavioral Psychology; Elsevier: Amsterdam, The Netherlands, 2017. [CrossRef]

64. Wang, P.; Li, X.; Li, X.; Yang, W.; Yu, S. Blood plasma of patients with Parkinson's disease increases alpha-synuclein aggregation and neurotoxicity. Parkinson's Dis. 2016, 2016, 7596482. [CrossRef] [PubMed]

65. Hisamichi, M.; Kawarazaki, H.; Oroku, M.; Tsuruoka, K.; Sakurada, T.; Shirai, S.; Kido, R.; Kimura, K.; Shibagaki, Y. Risk factors for allergic reaction at initial therapeutic plasma exchange in a single-center study: Beware of high rates of severe allergic reaction. Ren. Replace. Ther. 2016, 2, 67. [CrossRef]

66. Langston, J.W.; Wiley, J.C.; Tagliati, M. Optimizing Parkinson's disease diagnosis: The role of a dual nuclear imaging algorithm. NPJ Parkinson's Dis. 2018, 4, 5. [CrossRef]

67. Snow, B.; Mulroy, E.; Bok, A.; Simpson, M.; Smith, A.; Taylor, K.; Lockhart, M.; Lam, B.B.J.; Frampton, C.; Schweder, P.; et al. A phase IIb, randomised, double-blind, placebo-controlled, dose-ranging investigation of the safety and efficacy of NTCELL®[immunoprotected (alginate-encapsulated) porcine choroid plexus cells for xenotransplantation] in patients with Parkinson's disease. Parkinsonism Relat. Disord. 2019, 61, 88-93. [CrossRef] [PubMed]

68. NTcell. Available online: https://lctglobal.com/research/ntcell (accessed on 26 May 2021).

69. Freed, C.R.; Greene, P.E.; Breeze, R.E.; Tsai, W.Y.; DuMouchel, W.; Kao, R.; Dillon, S.; Winfield, H.; Culver, S.; Trojanowski, J.Q.; et al. Transplantation of embryonic dopamine neurons for severe Parkinson's disease. N. Engl. J. Med. 2001, 344, 710-719. [CrossRef]

70. Nakamura, T.; Dhawan, V.; Chaly, T.; Fukuda, M.; Ma, Y.; Breeze, R.; Greene, P.; Fahn, S.; Freed, C.; Eidelberg, D. Blinded positron emission tomography study of dopamine cell implantation for Parkinson's disease. Ann. Neurol. 2001, 50, 181-187. [CrossRef]

71. Ma, Y.; Feigin, A.; Dhawan, V.; Fukuda, M.; Shi, Q.; Greene, P.; Breeze, R.; Fahn, S.; Freed, C.; Eidelberg, D. Dyskinesia after fetal cell transplantation for parkinsonism: A PET study. Ann. Neurol. 2002, 52, 628-634. [CrossRef]

72. Trott, C.T.; Fahn, S.; Greene, P.; Dillon, S.; Winfield, H.; Winfield, L.; Kao, R.; Eidelberg, D.; Freed, C.R.; Breeze, R.E.; et al. Cognition following bilateral implants of embryonic dopamine neurons in PD: A double blind study. Neurology 2003, 60, 1938-1943. [CrossRef]

73. Björklund, A.; Dunnett, S.B.; Brundin, P.; Stoessl, A.J.; Freed, C.R.; Breeze, R.E.; Levivier, M.; Peschanski, M.; Studer, L.; Barker, R. Neural transplantation for the treatment of Parkinson's disease. Lancet Neurol. 2003, 2, 437-445. [CrossRef]

74. Freed, C.R.; Leehey, M.A.; Zawada, M.; Bjugstad, K.; Thompson, L.; Breeze, R.E. Do patients with Parkinson's disease benefit from embryonic dopamine cell transplantation? J. Neurol. 2003, 250 (Suppl. 3), iii44-iii46. [CrossRef]

75. Gordon, P.H.; Yu, Q.; Qualls, C.; Winfield, H.; Dillon, S.; Greene, P.E.; Fahn, S.; Breeze, R.E.; Freed, C.R.; Pullman, S.L. Reaction time and movement time after embryonic cell implantation in Parkinson disease. Arch. Neurol. 2004, 61, 858-861. [CrossRef] [PubMed]

76. McRae, C.; Cherin, E.; Yamazaki, T.G.; Diem, G.; Vo, A.H.; Russell, D.; Ellgring, J.H.; Fahn, S.; Greene, P.; Dillon, S.; et al. Effects of perceived treatment on quality of life and medical outcomes in a double-blind placebo surgery trial. Arch. Gen. Psychiatry 2004, 61, 412-420. [CrossRef]

77. Politis, M.; Lindvall, O. Clinical application of stem cell therapy in Parkinson's disease. BMC Med. 2012, 10, 1. [CrossRef]

78. Axelsen, T.M.; Woldbye, D.P.D. Gene therapy for Parkinson's disease, an update. J. Parkinson's Dis. 2018, 8, 195-215. [CrossRef] [PubMed]

79. Lang, A.E.; Gill, S.; Patel, N.K.; Lozano, A.; Nutt, J.G.; Penn, R.; Brooks, D.J.; Hotton, G.; Moro, E.; Heywood, P.; et al. Randomized controlled trial of intraputamenal glial cell line-derived neurotrophic factor infusion in Parkinson disease. Ann. Neurol. 2006, 59, 459-466. [CrossRef] [PubMed]

80. Isacson, O.; Kordower, J.H. Future of cell and gene therapies for Parkinson's disease. Ann. Neurol. 2008, 64, S122-S138. [CrossRef] [PubMed]

81. Schmidt, H.D.; Banasr, M.; Duman, R.S. Future antidepressant targets: Neurotrophic factors and related signaling cascades. Drug Discov. Today Strat. 2008, 5, 151-156. [CrossRef]

82. Valdés, P.; Schneider, B.L. Gene therapy: A promising approach for neuroprotection in Parkinson's disease? Front. Neuroanat. 2016, 10, 123. [CrossRef]

83. Bryson, S. Gene Therapy Trial Patients, in Death, Helping Show What Did and Didn't Work. Parkinson's News Today, 26 March 2020.

84. Time to Try Again: Gene-Based Therapy for Neurodegeneration: Society for Neuroscience Annual Meeting 2019. Available online: https:/ / www.alzforum.org/news/conference-coverage/time-try-again-gene-based-therapy-neurodegeneration (accessed on 25 May 2020). 
85. Coune, P.G.; Schneider, B.L.; Aebischer, P. Parkinson's disease: Gene therapies. Cold Spring Harb. Perspect. Med. 2012,2 , a009431. [CrossRef] [PubMed]

86. Hudry, E.; Vandenberghe, L.H. Therapeutic AAV gene transfer to the nervous system: A clinical reality. Neuron 2019, 101, 839-862. [CrossRef] [PubMed]

87. Hinderer, C.; Katz, N.; Buza, E.L.; Dyer, C.; Goode, T.; Bell, P.; Richman, L.K.; Wilson, J.M. Severe toxicity in nonhuman primates and piglets following high-dose intravenous administration of an adeno-associated virus vector expressing human SMN. Hum. Gene Ther. 2018, 29, 285-298. [CrossRef]

88. Sangkuhl, K.; Klein, T.E.; Altman, R.B. Selective serotonin reuptake inhibitors pathway. Pharm. Genom. 2009, 19, 907-909. [CrossRef]

89. Baumgarten, H.G.; Grozdanovic, Z. Psychopharmacology of central serotonergic systems. Pharmacopsychiatry 1995, 28, 73-79. [CrossRef]

90. Tani, Y.; Ogata, A.; Koyama, M.; Inoue, T. Effects of piclozotan (SUN N4057), a partial serotonin 1A receptor agonist, on motor complications induced by repeated administration of levodopa in parkinsonian rats. Eur. J. Pharmacol. 2010, 649, $218-223$. [CrossRef]

91. Abdala, A.P.; Lioy, D.T.; Garg, S.K.; Knopp, S.J.; Paton, J.F.R.; Bissonnette, J.M. Effect of sarizotan, a 5-HT1a and D2-like receptor agonist, on respiration in three mouse models of rett syndrome. Am. J. Respir. Cell Mol. Biol. 2014, 50, 1031-1039. [CrossRef]

92. SYN120 Fails to Show Efficacy Against Parkinson Dementia in Phase 2a SYNAPSE Trial. Available online: https: / consultqd. clevelandclinic.org/syn120-fails-to-show-efficacy-against-parkinson-dementia-in-phase-2a-synapse-trial/ (accessed on 20 November 2020).

93. Brea, J.; Castro-Palomino, J.; Yeste, S.; Cubero, E.; Párraga, A.; Domínguez, E.; Loza, M.I. Emerging opportunities and concerns for drug discovery at serotonin 5-HT2B receptors. Curr. Top. Med. Chem. 2010, 10, 493-503. [CrossRef] [PubMed]

94. Dias, V.; Junn, E.; Mouradian, M.M. The role of oxidative stress in Parkinson's disease. J. Parkinson's Dis. 2013,3 , 461-491. [CrossRef] [PubMed]

95. Liu, C. Targeting the cholinergic system in Parkinson's disease. Acta Pharmacol. Sin. 2020, 41, 453-463. [CrossRef] [PubMed]

96. Rascol, O.; Poewe, W.; Lees, A.; Aristin, M.; Salin, L.; Juhel, N.; Waldhauser, L.; Schindler, T.; Group, A.S. Tesofensine (NS 2330), a monoamine reuptake inhibitor, in patients with advanced Parkinson disease and motor fluctuations: The ADVANS study. Arch. Neurol. 2008, 65, 577-583. [CrossRef]

97. Hauser, R.A.; Salin, L.; Juhel, N.; Konyago, V.L. Randomized trial of the triple monoamine reuptake inhibitor NS 2330 (tesofensine) in early Parkinson's disease. Mov. Disord. 2007, 22, 359-365. [CrossRef]

98. Bara-Jimenez, W.; Dimitrova, T.; Sherzai, A.; Favit, A.; Mouradian, M.M.; Chase, T.N. Effect of monoamine reuptake inhibitor NS 2330 in advanced Parkinson's disease. Mov. Disord. 2004, 19, 1183-1186. [CrossRef]

99. Carlson, A.B.; Kraus, G.P. Physiology, cholinergic receptors. In StatPearls; StatPearls Publishing, Copyright (C) 2020. StatPearls Publishing LLC.: Treasure Island, FL, USA, 2020.

100. Villard, V.; Espallergues, J.; Keller, E.; Vamvakides, A.; Maurice, T. Anti-amnesic and neuroprotective potentials of the mixed muscarinic receptor/sigma1 $(\sigma 1)$ ligand ANAVEX2-73, a novel aminotetrahydrofuran derivative. J. Psychopharmacol. 2010, 25, 1101-1117. [CrossRef]

101. Villafane, G.; Thiriez, C.; Audureau, E.; Straczek, C.; Kerschen, P.; Cormier-Dequaire, F.; Van Der Gucht, A.; Gurruchaga, J.M.; Quéré-Carne, M.; Evangelista, E.; et al. High-dose transdermal nicotine in Parkinson's disease patients: A randomized, open-label, blinded-endpoint evaluation phase 2 study. Eur. J. Neurol. 2018, 25, 120-127. [CrossRef] [PubMed]

102. Goldenberg, M.M. Medical management of Parkinson's disease. Pharm. Ther. 2008, 33, 590-606.

103. Barth, A.L.; Schneider, J.S.; Johnston, T.H.; Hill, M.P.; Brotchie, J.M.; Moskal, J.R.; Cearley, C.N. NYX-458 improves cognitive performance in a primate Parkinson's disease model. Mov. Disord. 2020, 35, 640-649. [CrossRef] [PubMed]

104. Khan, M.A.; Houck, D.R.; Gross, A.L.; Zhang, X.L.; Cearley, C.; Madsen, T.M.; Kroes, R.A.; Stanton, P.K.; Burgdorf, J.; Moskal, J.R. NYX-2925 Is a novel NMDA receptor-specific spirocyclic- $\beta$-lactam that modulates synaptic plasticity processes associated with learning and memory. Int J. Neuropsychopharmacol 2018, 21, 242-254. [CrossRef] [PubMed]

105. Wood, P.L. NMDA antagonists for stroke and head trauma: Current status. Expert Opin. Investig. Drugs 1998, 7, 1505-1508. [CrossRef]

106. Olivares, D.; Deshpande, V.K.; Shi, Y.; Lahiri, D.K.; Greig, N.H.; Rogers, J.T.; Huang, X. N-methyl D-aspartate (NMDA) receptor antagonists and memantine treatment for Alzheimer's disease, vascular dementia and Parkinson's disease. Curr. Alzheimer Res. 2012, 9, 746-758. [CrossRef] [PubMed]

107. Andringa, G.; Eshuis, S.; Perentes, E.; Maguire, R.P.; Roth, D.; Ibrahim, M.; Leenders, K.L.; Cools, A.R. TCH346 prevents motor symptoms and loss of striatal FDOPA uptake in bilaterally MPTP-treated primates. Neurobiol. Dis. 2003, 14, 205-217. [CrossRef]

108. Grotegut, P.; Perumal, N.; Kuehn, S.; Smit, A.; Dick, H.B.; Grus, F.H.; Joachim, S.C. Minocycline reduces inflammatory response and cell death in a S100B retina degeneration model. J. Neuroinflammation 2020, 17, 375. [CrossRef] [PubMed]

109. West, A.B. Achieving neuroprotection with LRRK2 kinase inhibitors in Parkinson disease. Exp. Neurol. 2017, 298, 236-245. [CrossRef]

110. Maroney, A.C.; Finn, J.P.; Connors, T.J.; Durkin, J.T.; Angeles, T.; Gessner, G.; Xu, Z.; Meyer, S.L.; Savage, M.J.; Greene, L.A.; et al. Cep-1347 (KT7515), a semisynthetic inhibitor of the mixed lineage kinase family. J. Biol. Chem. 2001, 276, 25302-25308. [CrossRef] [PubMed] 
111. Mixed lineage kinase inhibitor CEP-1347 fails to delay disability in early Parkinson disease. Neurology 2007, 69, 1480-1490. [CrossRef]

112. Mandhane, S.D.S.; Jani, K.; Sengupta, P.; Patel, A.; Bambal, R.; Ramanathan, V.; Zala, Y.; Dharmadhikari, N.; Rao, C.; Raghavan, A.; et al. K0706, a potent orally bioavailable brain-penetrating selective inhibitor of cABL protein tyrosine kinase, exhibits neuroprotective activity in preclinical models of Parkinson's disease. In Proceedings of the MDS Abstracts, Agora 3 West, Level 3 , Nice, France, 22-26 September 2019; p. 970.

113. Lodish, M.B. Clinical review: Kinase inhibitors: Adverse effects related to the endocrine system. J. Clin. Endocrinol. Metab. 2013, 98, 1333-1342. [CrossRef] [PubMed]

114. Hartmann, J.T.; Haap, M.; Kopp, H.G.; Lipp, H.P. Tyrosine kinase inhibitors-a review on pharmacology, metabolism and side effects. Curr. Drug Metab. 2009, 10, 470-481. [CrossRef]

115. Jucaite, A.; Svenningsson, P.; Rinne, J.O.; Cselényi, Z.; Varnäs, K.; Johnström, P.; Amini, N.; Kirjavainen, A.; Helin, S.; Minkwitz, M.; et al. Effect of the myeloperoxidase inhibitor AZD3241 on microglia: A PET study in Parkinson's disease. Brain 2015, 138, 2687-2700. [CrossRef]

116. Gellhaar, S.; Sunnemark, D.; Eriksson, H.; Olson, L.; Galter, D. Myeloperoxidase-immunoreactive cells are significantly increased in brain areas affected by neurodegeneration in Parkinson's and Alzheimer's disease. Cell Tissue Res. 2017, 369, 445-454. [CrossRef] [PubMed]

117. Franco, R.; Navarro, G. Adenosine A2A receptor antagonists in neurodegenerative diseases: Huge potential and huge challenges. Front. Psychiatry 2018, 9, 68. [CrossRef] [PubMed]

118. Vernalis Licenses Proprietary Adenosine Receptor Antagonist Technology, Including Lead Compound V81444, For, Development and Commercialisation. Available online: https:/ / www.vernalis.com/vernalis-licenses-proprietary-adenosine-receptorantagonist-technology-including-lead-compound-v81444-for-development-and-commercialisation/ (accessed on 26 November 2020).

119. Cheong, S.L.; Federico, S.; Spalluto, G.; Klotz, K.-N.; Pastorin, G. The current status of pharmacotherapy for the treatment of Parkinson's disease: Transition from single-target to multitarget therapy. Drug Discov. Today 2019, 24, 1769-1783. [CrossRef]

120. Chen, J.-F.; Xu, K.; Petzer, J.P.; Staal, R.; Xu, Y.-H.; Beilstein, M.; Sonsalla, P.K.; Castagnoli, K.; Castagnoli, N.; Schwarzschild, M.A. Neuroprotection by caffeine and A2A adenosine receptor inactivation in a model of Parkinson's disease. J. Neurosci. 2001, 21, RC143. [CrossRef]

121. Kumar, H.; Lim, H.-W.; More, S.V.; Kim, B.-W.; Koppula, S.; Kim, I.S.; Choi, D.-K. The role of free radicals in the aging brain and Parkinson's disease: Convergence and parallelism. Int. J. Mol. Sci. 2012, 13, 10478-10504. [CrossRef] [PubMed]

122. Lin, M.-W.; Lin, C.C.; Chen, Y.-H.; Yang, H.-B.; Hung, S.-Y. Celastrol inhibits dopaminergic neuronal death of Parkinson's disease through activating mitophagy. Antioxidants 2020, 9, 37. [CrossRef] [PubMed]

123. Sechi, G.; Deledda, M.G.; Bua, G.; Satta, W.M.; Deiana, G.A.; Pes, G.M.; Rosati, G. Reduced intravenous glutathione in the treatment of early Parkinson's disease. Prog. Neuro Psychopharmacol. Biol. Psychiatry 1996, 20, 1159-1170. [CrossRef]

124. Lobo, V.; Patil, A.; Phatak, A.; Chandra, N. Free radicals, antioxidants and functional foods: Impact on human health. Pharm. Rev. 2010, 4, 118-126. [CrossRef] [PubMed]

125. Kim, J.; Li, H.; Kim, H.; Yang, H.O. Protective effect of WIN-1001X, an herbal extract, on Parkinson's disease experimental model via autophagy enhancement. Planta Med. 2014, 80, P1L98. [CrossRef]

126. Ojo-Amaize, E.A.; Cottam, H.B. Short review of current research on the development of hypoestoxide as a therapeutic agent for Parkinson's disease. J. Neurol Neurophysiol. 2016, 7, 2. [CrossRef]

127. Kim, C.; Ojo-Amaize, E.; Spencer, B.; Rockenstein, E.; Mante, M.; Desplats, P.; Wrasidlo, W.; Adame, A.; Nchekwube, E.; Oyemade, O; ; et al. Hypoestoxide reduces neuroinflammation and $\alpha$-synuclein accumulation in a mouse model of Parkinson's disease. $J$. Neuroinflamm. 2015, 12, 236. [CrossRef]

128. Phase 2A Study of GM 608 in Mild to Moderate Parkinson Disease: GM 608 in A Phase IIA Pilot Double-blinded, Randomized, Placebo Controlled Trial in Mild to Moderate Parkinson Disease. Available online: https://ichgcp.net/clinical-trials-registry/ NCT01850381 (accessed on 24 December 2020).

129. McFarthing, K.; Larson, D.; Simuni, T. Clinical trial highlights-GLP-1 agonists. J. Parkinson's Dis. 2020, 10, 355-368. [CrossRef]

130. Dorsey, E.R.; Sherer, T.; Okun, M.S.; Bloem, B.R. The emerging evidence of the parkinson pandemic. J. Parkinson's Dis. 2018, 8, S3-S8. [CrossRef] [PubMed]

131. Chou, K.L. Diagnosis and Differential Diagnosis of Parkinson Disease; UpToDate: Waltham, MA, USA, 2017.

132. Manfredsson, F.P.; Polinski, N.K.; Subramanian, T.; Boulis, N.; Wakeman, D.R.; Mandel, R.J. The future of GDNF in Parkinson's disease. Front. Aging Neurosci. 2020, 12, 388. [CrossRef]

133. Verschuur, C.V.M.; Suwijn, S.R.; Boel, J.A.; Post, B.; Bloem, B.R.; van Hilten, J.J.; van Laar, T.; Tissingh, G.; Munts, A.G.; Deuschl, G.; et al. Randomized delayed-start trial of levodopa in Parkinson's disease. N. Engl. J. Med. 2019, 380, 315-324. [CrossRef]

134. DeMaagd, G.; Philip, A. Parkinson's disease and its management: Part 3: Nondopaminergic and nonpharmacological treatment options. Pharm. Ther. 2015, 40, 668-679.

135. Münchau, A.; Bhatia, K.P. Pharmacological treatment of Parkinson's disease. Postgrad. Med. J. 2000, 76, 602. [CrossRef] [PubMed]

136. Dong, J.; Cui, Y.; Li, S.; Le, W. Current pharmaceutical treatments and alternative therapies of Parkinson's disease. Curr. Neuropharmacol. 2016, 14, 339-355. [CrossRef] [PubMed] 
137. Dodel, R.C.; Eggert, K.M.; Singer, M.S.; Eichhorn, T.E.; Pogarell, O.; Oertel, W.H. Costs of drug treatment in Parkinson's disease. Mov. Disord. 1998, 13, 249-254. [CrossRef]

138. Charles, D.; Tolleson, C.; Davis, T.L.; Gill, C.E.; Molinari, A.L.; Bliton, M.J.; Tramontana, M.G.; Salomon, R.M.; Kao, C.; Wang, L.; et al. Pilot study assessing the feasibility of applying bilateral subthalamic nucleus deep brain stimulation in very early stage Parkinson's disease: Study design and rationale. J. Parkinson's Dis. 2012, 2, 215-223. [CrossRef]

139. Hamani, C.; Pilitsis, J.; Rughani, A.I.; Rosenow, J.M.; Patil, P.G.; Slavin, K.S.; Abosch, A.; Eskandar, E.; Mitchell, L.S.; Kalkanis, S. Deep brain stimulation for obsessive-compulsive disorder: Systematic review and evidence-based guideline sponsored by the American society for stereotactic and functional neurosurgery and the congress of neurological surgeons (CNS) and endorsed by the CNS and American association of neurological surgeons. Neurosurgery 2014, 75, 327-333. [CrossRef]

140. Follett, K.A.; Weaver, F.M.; Stern, M.; Hur, K.; Harris, C.L.; Luo, P.; Marks, W.J.; Rothlind, J.; Sagher, O.; Moy, C.; et al. Pallidal versus subthalamic deep-brain stimulation for Parkinson's disease. N. Engl. J. Med. 2010, 362, 2077-2091. [CrossRef]

141. Weaver, F.M.; Follett, K.A.; Stern, M.; Luo, P.; Harris, C.L.; Hur, K.; Marks, W.J., Jr.; Rothlind, J.; Sagher, O.; Moy, C.; et al. Randomized trial of deep brain stimulation for Parkinson disease: Thirty-six-month outcomes. Neurology 2012, $79,55-65$. [CrossRef]

142. Lozano, A.M.; Lipsman, N.; Bergman, H.; Brown, P.; Chabardes, S.; Chang, J.W.; Matthews, K.; McIntyre, C.C.; Schlaepfer, T.E.; Schulder, M.; et al. Deep brain stimulation: Current challenges and future directions. Nat. Rev. Neurol. 2019, 15, 148-160. [CrossRef] [PubMed]

143. Dang, T.T.H.; Rowell, D.; Connelly, L.B. Cost-effectiveness of deep brain stimulation with movement disorders: A systematic review. Mov. Disord. Clin. Pract. 2019, 6, 348-358. [CrossRef]

144. Nirenberg, M.J.; Waters, C. Compulsive eating and weight gain related to dopamine agonist use. Mov. Disord. 2006, 21, 524-529. [CrossRef]

145. Bonuccelli, U.; Del Dotto, P.; Rascol, O. Role of dopamine receptor agonists in the treatment of early Parkinson's disease. Parkinsonism Relat. Disord. 2009, 15, S44-S53. [CrossRef]

146. Kujawa, K.; Leurgans, S.; Raman, R.; Blasucci, L.; Goetz, C.G. Acute orthostatic hypotension when starting dopamine agonists in Parkinson's disease. Arch. Neurol. 2000, 57, 1461-1463. [CrossRef]

147. Hypersexuality due to dopaminergic drugs. Prescrire Int. 2005, 14, 224.

148. Pinder, R.M. Pathological gambling and dopamine agonists: A phenotype? Neuropsychiatr. Dis. Treat. 2007, 3, 1-2. [CrossRef]

149. Borovac, J.A. Side effects of a dopamine agonist therapy for Parkinson's disease: A mini-review of clinical pharmacology. Yale J. Biol. Med. 2016, 89, 37-47. [PubMed]

150. Chia, R.; Sabir, M.S.; Bandres-Ciga, S.; Saez-Atienzar, S.; Reynolds, R.H.; Gustavsson, E.; Walton, R.L.; Ahmed, S.; Viollet, C.; Ding, J.; et al. Genome sequencing analysis identifies new loci associated with Lewy body dementia and provides insights into its genetic architecture. Nat. Genet. 2021, 53, 294-303. [CrossRef] [PubMed]

151. Goswami, R.; Subramanian, G.; Silayeva, L.; Newkirk, I.; Doctor, D.; Chawla, K.; Chattopadhyay, S.; Chandra, D.; Chilukuri, N.; Betapudi, V. Gene therapy leaves a vicious cycle. Front. Oncol. 2019, 9, 297. [CrossRef]

152. Qian, H.-Z.; Vermund, S.H.; Kaslow, R.A.; Coffey, C.S.; Chamot, E.; Yang, Z.; Qiao, X.; Zhang, Y.; Shi, X.; Jiang, Y.; et al. Coinfection with HIV and hepatitis $\mathrm{C}$ virus in former plasma/blood donors: Challenge for patient care in rural China. AIDS 2006, 20, 1429-1435. [CrossRef]

153. Kleinman, S.H.; Lelie, N.; Busch, M.P. Infectivity of human immunodeficiency virus-1, hepatitis C virus, and hepatitis B virus and risk of transmission by transfusion. Transfusion 2009, 49, 2454-2489. [CrossRef]

154. Cicchetti, A.; Berrino, A.; Casini, M.; Codella, P.; Facco, G.; Fiore, A.; Marano, G.; Marchetti, M.; Midolo, E.; Minacori, R.; et al. Health technology assessment of pathogen reduction technologies applied to plasma for clinical use. Blood Transfus. 2016, 14, 287-386. [CrossRef]

155. From the centers for disease control and prevention. Outbreak of hepatitis c associated with intravenous immunoglobulin administration-United States, October 1993-June 1994. JAMA 1994, 272, 424-425. [CrossRef]

156. Hellstern, P.; Solheim, B.G. The Use of solvent/detergent treatment in pathogen reduction of plasma. Transfus. Med. Hemother. 2011, 38, 65-70. [CrossRef] [PubMed]

157. GrÖNer, A. Pathogen safety of plasma-derived products-Haemate®P/Humate-P®. Haemophilia 2008, 14, 54-71. [CrossRef]

158. Guo, Y.; Tian, X.; Wang, X.; Xiao, Z. Adverse effects of immunoglobulin therapy. Front. Immunol. 2018, 9, 1299. [CrossRef]

159. Brecher, M.E.; Hay, S.N. Bacterial contamination of blood components. Clin. Microbiol. Rev. 2005, 18, 195-204. [CrossRef]

160. Hingorani, A.D.; Kuan, V.; Finan, C.; Kruger, F.A.; Gaulton, A.; Chopade, S.; Sofat, R.; MacAllister, R.J.; Overington, J.P.; Hemingway, H.; et al. Improving the odds of drug development success through human genomics: Modelling study. Sci. Rep. 2019, 9, 18911. [CrossRef] [PubMed]

161. Becerra, J.E.; Zorro, O.; Ruiz-Gaviria, R.; Castañeda-Cardona, C.; Otálora-Esteban, M.; Henao, S.; Navarrete, S.; Acevedo, J.C.; Rosselli, D. Economic analysis of deep brain stimulation in Parkinson disease: Systematic review of the literature. World Neurosurg. 2016, 93, 44-49. [CrossRef] [PubMed]

162. Marras, C.; Beck, J.C.; Bower, J.H.; Roberts, E.; Ritz, B.; Ross, G.W.; Abbott, R.D.; Savica, R.; Van Den Eeden, S.K.; Willis, A.W.; et al. Prevalence of Parkinson's disease across North America. NPJ Parkinson's Dis. 2018, 4, 21. [CrossRef] 